\title{
ARNAU DE MONTRODON \\ Y LA CATEDRAL DE SAN CARLOMAGNO \\ SOBRE LA IMAGEN Y EL CULTO \\ AL EMPERADOR CAROLINGIO EN GERONA
}

\author{
JOAN MOLINA FIGUERAS ${ }^{1}$
}

Resumen: En 1345 se institucionalizó en la catedral de Gerona el singular culto a San Carlomango. Las raices, y para muchos las razones, de dicha fiesta se hallan en la existencia de una antigua leyenda local, cuyos testimónios conocidos se remontan al siglo XI. Sin embargo, un detenido análisis de los hechos que marcaron la vida de la catedral durante la larga permanencia de Arnau de Montrodon en la misma - primero en calidad de canónigo (1297-1335) y después como obispo (1333-1348)- nos permitirán comprobar que la promoción del culto a San Carlomagno se inscribe en un complejo programa de exaltación ideológica y simbólica de la sede gerundense diseñado por este notable e inquieto eclesiástico.

Palabras Clave: Carlomagno; Hagiografía; Culto Imperial; Liturgia Imperial; Catedral de Gerona; Arnau de Montrodon.

Abstract: In 1345, the unique worship of Saint Charlemagne was institutionalized in the cathedral of Gerona. The roots (and for many, the reasons) of this celebration are found in the existence of an old local legend, the well-known testimonies to which go back to the eleventh century. Nevertheless, a lengthy analysis of the facts that marked the life of the cathedral during the long permanence Arnau de Montrodon had there-first in quality of canon (1297-1335) and later as bishop (1333-1348)- make it possible for us to verify that the promotion of the cult to San Charlemagne falls within a complex program of ideological and symbolic exaltation of the See of Girona that was designed by this notable and restlessly active ecclesiastic.

Keywords: Charlemagne; Hagiography; Imperial Cult; Imperial Liturgy; Gerona Cathedral; Arnau de Montrodon.

\section{SUMARIO}

1. El recuerdo de Carlomagno en la catedral.- 2. Claves y lecturas de un culto.

${ }^{1}$ Profesor en el Departament de Geografia, Història i Història de l'Art, Facultat de Lletres, Universitat de Girona. 2004 .

Fecha de recepción del artículo: febrero 2004. Fecha de aceptación y versión final: abril

«Anuario de Estudios Medievales», 34/1 (2004), pp. 417- 454.- ISSN 0066-5061. 
En la espléndida colección del pequeño pero delicioso Museo de la Catedral de Gerona podemos admirar una de las imágenes más representativas e interesantes de la escultura trecentista catalana. Me refiero a la refinada y elegante figura en alabastro de San Carlomagno ${ }^{2}$. La efigie del emperador carolingio se presenta bajo una curiosa apariencia: ciñe una corona flordelisa$\mathrm{da}$; viste un brial con ribetes adornados y una gran capa decorada con motivos fitomórficos; y luce los blasones de Aragón, grabados tanto en la fimbria del brial como en las vainas de la espada y la daga que penden del cíngulo (fig. 1). Junto a estos detalles propios de la iconografía áulica catalano-aragonesa se encuentran otros que van más allá de los estereotipados modelos practicados en este ámbito ${ }^{3}$. Uno de ellos sería el gesto naturalista de la mano izquierda, que hace ademán de coger el cíngulo en lugar de sostener el orbe con la cruz o cualquier otro atributo de poder. Otro aspecto, aún más sorprendente, es la representación a los pies del monarca de un grupo de bestias, tres de ellas seres híbridos teriomórficos mientras la cuarta se asemeja a un mastín. Dada la naturaleza monstruosa de las criaturas el paralelo más claro se halla en la triunfal iconografía cristológica, pero también mariana e incluso papal, inspirada en el salmo 90.13 (Pisarás sobre áspides y víboras/ y hollarás al leoncillo y el dragón $)^{4}$. La utilización de esta fuente y su particular traducción visual constituyen, desde luego, un hecho absolutamente excepcional en el terreno de las imágenes áulicas de la Corona de Aragón y

${ }^{2}$ La pieza cuenta con una abundante bibliografía. Entre los estudios monográficos destacan los de E.C. GIRBAL, La estatua de Carlomagno, "Revista de Gerona", 13 (1889), pp. 13-24; BARÓN DE CUATRO TORRES, La estatua llamada de San Carlomagno, "Boletín de la Sociedad española de Excursiones", 2 (1894), pp. 35-38; C. PÉREZ, En torno a Jaume Cascalls, Su obra en Girona, "D'Art", 5 (1979,) pp. 69-74; P. FreIXAS, Jaume Cascalls o Aloi de Montbrai. Estàtua de Rei o de Sant Carlemany en Millenum. Catàleg, Barcelona, 1989, p. 278; R. TERÉs, Escultura antiga i medieval. L'època gòtica, en Art de Catalunya. Ars Cataloniae, Barcelona, 1997, pp. 276-277; J. MolinA, San Carlomagno, en I. BANGO (ed.), Maravillas de la España medieval. Tesoro sagrado y monarquía, s.1., 2001, pp. 146-148.

${ }^{3}$ Un último y detallado estudio sobre los retratos mayestáticos de los monarcas de la Corona de Aragón y sus principales rasgos iconográficos en A. SERRA, La serie dinástica de la Corona de Aragón en Genealogía de los Reyes de Aragón y Condes de Barcelona, Valencia, 1997, pp. 59-71 (una versión más accesible, ID., La historia de la dinastía en imágenes: Martín el Humano y el rollo genealógico de la Corona de Aragón, "Locus Amoenus", 6 (2002-2003), pp. 65-71).

${ }^{4} \mathrm{El}$ motivo ya se encuentra en imágenes de Carlomagno ejecutadas en su propia época, como es el caso del famoso relicario de Eguinardo. Vid. C. FRUGONI, L'ideologia del potere imperiale nella Cattedra di S. Pietro, "Bullettino dell'istituto Storico Italiano per il Medioevo e Archivio Muratoniano", 86 (1976-1977), pp. 61-181. Sobre su sentido triunfal y su aplicación en representaciones papales, vid. C. WALTER, Papal Political Imaginery in the Medieval Lateran Palace, en ID., Prayer and Power in Byzantine and Papal Imagery, Norfolk-Aldershot, 1993, pp. 109-136.

«Anuario de Estudios Medievales», 34/1 (2004), pp. 417- 454.- ISSN 0066-5061. 
habla, por sí misma, de la grandilocuente y heterodoxa iconografía que se quiso imprimir a la efigie gerundense.

Pese a la falta de documentos que aporten noticias precisas sobre las circunstancias que rodearon el encargo de la figura disponemos de datos suficientes para establecer una serie de fundadas hipótesis que nos aclaren su historia. Por un lado las características formales y estilísticas ofrecen un fuerte parentesco con una serie de obras realizadas en la órbita del escultor Jaume Cascalls en torno a $1340-1350^{5}$. Con aún mayor seguridad podemos afirmar

${ }^{5}$ Dicha atribución no está exenta de dudas y plantea una problemática que va mucho más allá de lo que aquí se pretende estudiar. Pese a ello, y puesto que la efigie es el objeto entorno al cual girará nuestro discurso, parece necesario esbozar los principales perfiles de la cuestión. Fue Duran i Sanpere el primero en incluir el San Carlomagno en el catálogo de Jaume Cascalls. Vid. A. DURAN I SANPERE, Els retaules de pedra I, "Monumenta Cataloniae" I Barcelona, 1932, pp. 41-50; A. DURAN I SANPERE; J. AINAUD DE LASARTE, Escultura gòtica. (Ars Hispaniae VIII), Madrid, 1956, p. 208ss. Su propuesta ofrecía un alto grado de verosimilitud dados los evidentes vínculos estilísticos entre la imagen gerundense y el retablo de Cornellà de Conflent (ca. 1345) única obra firmada de Cascalls, y otras producciones adscritas a su catálogo, como el Cristo yacente de Sant Feliu de Gerona, el pseudo-Antonio y una cabeza de Cristo -éstos dos últimos conservados en el Museu Nacional d'Art de Catalunya. Sin embargo, el descubrimiento por parte de P. Freixas de que el Santo Sepulcro de San Feliu, al que pertenece el Cristo yacente conservado en la misma colegiata, había sido contratado por Aloi de Montbrai vino a complicar el asunto (P. FrEIXAS, L'obra del mestre Aloi a Girona, "Annals de l'Institut d'Estudis Gironins", XXVI (1982-1983), pp. 77-85; ID. L'art gòtic a Girona. Segles XIII-XV, Girona, 1983, pp. 114117. ID., Aloi de Montbrai. Crist jacent d'un sant sepulcre en Thesaurus. L'art als bisbats de Catalunya 1000-1800, Barcelona, 1985, pp. 182-184). A la vista de los textos exhumados, ¿cabía pensar en la paternidad de Aloi sobre una buena parte de las obras tradicionalmente atribuidas a Cascalls? Naturalmente la evidencia documental parecía que obligaba a seguir esta vía. De hecho así lo llegó a plantear el mismo Freixas al postular la autoría de Aloi sobre el San Carlomagno (ID., Jaume Cascalls o Aloi de Montbrai. Estàtua de Rei o de Sant Carlemany en Millenum. Catâleg, Barcelona, 1989, p. 278). No obstante hay un aspecto que no puede ser obviado: la atenta inspección visual de las diferentes obras contratadas por Aloi de Montbrai que han llegado hasta nuestros días revela que nos hallamos ante creaciones no sólo de distinta calidad de ejecución sino también fruto de diversas manos. Esta circunstancia ha llevado a suponer que quizás Aloi actuó más como un escultor-empresario que como un maestro convencional o, lo que es lo mismo, que adoptó el perfil de un cualificado y prestigioso profesional que para hacer frente a una importante e ingente demanda de proyectos no dudó en adoptar una variada serie de fórmulas que iban desde la asociación con otros escultores hasta la subcontratación de encargos. La hipótesis, que ha obtenido una notable fortuna, fue apuntada por J. YARZA, Artista-artesano en el gòtico catalán, "Lambard", III (1983-1985) p. 145. Un reciente y disectivo análisis de la cuestión en F. ESPAÑol, El gòtic català, Manresa, 2002, pp. 224-233. Por otro lado no deberíamos olvidar que en el año 1347 Aloi y Cascalls subscribieron un contrato de asociación, lo que podría explicar fácilmente la intervención del segundo en proyectos encargados al primero. Es por todo ello que, a la vista del estado actual de las investigaciones, la opción más plausible -dada la confusión que envuelve la personalidad artística de Aloi y la segura intervención de Cascalls en el retablo de Conflent- sigue siendo la de pensar que la imagen de San Carlomagno fue obrada por este último. Otras aportaciones sobre la figura y obra de Cascalls en PÉREZ, Entorno a Jaume Cascalls, op. cit; R. AlCOY y P. BESERAN, La fortuna de Jaume Cascalls en el context gironí, "Estudi General",10 (1990), pp. 93-118 y F. ESPAÑOL, Jaume Cascalls revisado: nuevas consideraciones y obras, "Locus Amoenus" 2 (1996) pp. 65-84. Señalemos, por otra parte, la relación apuntada entre la obra de Cascalls y los modelos surgidos del taller tolosano de Rieux (lbid., pp. 72-75); una vinculación que recientemente también se ha señalado para la imagen de San Carlomagno. Vid. G. Romano, Maestro de la Virgen de Narbona. Virgen con el Niño entronizada, c. 1370, en El Renacimiento Mediterráneo, Madrid 2001, pp. 236-239.

«Anuario de Estudios Medievales», 34/1 (2004), pp. 417- 454.- ISSN 0066-5061. 
que se trata de una imagen de culto. Dan fe de ello su diseño - una figura de bulto redondo de acusada frontalidad y con el reverso sin desbastar - pero, sobre todo, una serie de noticias indirectas que indican que nos hallamos ante la escultura que durante siglos presidió un altar dedicado a San Carlomagno, instituido el año 1345 por el obispo de Arnau de Montrodon en la capilla de los Cuatro Santos Mártires (fig. 2). Allí se encontraba aún, en el interior de una hornacina y sobre una leyenda que rezaba $S$. Carolus Magnus, cuando Jaime Villanueva visitó la sede gerundense a comienzos del siglo XIX ${ }^{6}$. De hecho permaneció en este lugar hasta el año 1884, momento en que el obispo Tomás Sivilla ordenó la supresión de la lectura del sermón que se leía en recuerdo del emperador carolingio así como el traslado de la efigie a las dependencias del Tesoro catedralicio, embrión del Museo donde hoy se expone ${ }^{7}$.

El acentuado carácter regio de la imagen, su fuerte individualización y la presencia de ciertos elementos como la daga o punyalet han impulsado a la mayoría de los especialistas a ver en el San Carlomagno gerundense un criptoretrato de Pedro el Ceremonioso, el monarca que gobernaba la Corona de Aragón en el momento en que fue tallado este alabastro (1336-1387). De este modo, nos invitan a pensar que nos encontramos ante un retrato del rey catalano-aragonés reconvertido en efigie imperial ${ }^{8}$. Algunos de ellos, decididos a dar una vuelta de tuerca más en este tipo de especulaciones, incluso han llegado proponer que, en realidad, se trata pura y simplemente de una imagen de Pedro el Ceremonioso?.

Cabe reconocer una cierta lógica a la primera parte de estos razonamientos. Es bien conocida la existencia de criptoretratos medievales, de imágenes en las que los escultores se sirvieron del rostro de un monarca

${ }^{6} \mathrm{~J}$. VillanueVa, Viaje literario a las iglesias de España, Vol. XIV, Madrid, 1850, p. 10.

${ }^{7}$ F. FITA, Los reys d'Aragó y la seu de Girona desde l'any 1462 al 1482, Barcelona, 1873, p. 48; E.C. GIRBAL, Carlomagno en Gerona, "Revista de Gerona", VIII (1884), pp. 225-229.

${ }^{8}$ BARÓN DE CuATro TORRES, La estatua, op. cit; PÉREZ, Entorno a Jaume Cascalls, op. cit., p. 72-73; TERÉs, Escultura, op. cit., p. 277, quién apunta que "la imatge gironina és un retrat idealitzat de Pere el Ceremoniós".

${ }^{9}$ Así se deduce del título del estudio que Freixas publicó en 1989. Vid. FreIXAS, Jaume Cascalls o Aloi de Montbrai. Estàtua de Rei o de Sant Carlemany, op. cit., p. 278, donde incluso se afirma que "tampoc és gaire clara la identitat de la peça". Por su parte, Romano ha señalado que se trata de un "retrato de cuerpo entero, probablemente Pedro el Ceremonioso (supuestamente Carlomagno)". ROMANO, Maestro de la Virgen, op. cit., p. 239. 
contemporáneo para evocar la memoria de un ilustre predecesor ${ }^{10}$. Sin ir más lejos esto fue lo que sucedió en el caso de la efigie de Carlomagno representada en su relicario de Aquisgrán, inspirada, con toda probabilidad, en la figura de su comitente, el emperador Federico Barbarroja. Por otra parte, no es menos cierto que durante todo su reinado Pedro el Ceremonioso auspició un gran número de retratos áulicos, cuyo resultado debe considerarse una suerte de compromiso entre identidad personal y estereotipos oficiales ${ }^{11}$. Dicha demanda resultó especialmente intensa en el terreno de la escultura, como bien lo demuestran las series dinásticas encargadas para el Palacio Real Mayor de Barcelona y el panteón del monasterio de Poblet o las diferentes imágenes aisladas en piedra o cera - ad similitudinem nostri, según reza en los documentos- que se instalaron en palacios y monasterios ${ }^{12}$.

Sin embargo, y aún reconociendo el peso de dichos argumentos, creo que resulta más verosímil abordar el proceso de construcción de la imagen gerundense a partir de otros planteamientos igualmente especulativos pero, probablemente, menos apriorísticos, menos condicionados por el intento de justificar la realización de un supuesto retrato de Pedro el Ceremonioso. Ante todo, si tenemos en cuenta que lo que se perseguía aquí era una receta de signo naturalista para evocar la figura de Carlomagno, habremos de reconocer que no era indispensable recurrir al criptoretrato de un monarca contemporáneo. Bien fácilmente podía hacerse uso de la fórmula del pseudo retrato, de un sistema de representación aplicado desde fines del siglo XII que consistía en otorgar una apariencia realista, e incluso ciertos rasgos psicológicos, a los retratos de personajes bíblicos o de insignes personajes fallecidos mucho

\footnotetext{
${ }^{10}$ M. BACCI, Artisti, corti, comuni, en E. CASTElnuovo; G. SAGGI (eds.), Arti e storia nel Medioevo, Vol. I (Tempi, Spazi Instituzioni), Turín, 2002, p. 678-679.

${ }^{11}$ Sobre el tema del retrato durante el reinado del monarca catalano-aragonés, vid. supra nota 3 y J. BRACONS, Operibus Monumentorum que fieri facere ordinamus: l'escultura al servei de Pere el Ceremoniós, en Pere el Ceremoniós i la seva època, Barcelona 1979, pp. 177-192; M. FALOMIR, Sobre los orígenes del retrato y la aparición del pintor de corte en la España bajomedieval, en "Boletín de Arte" XVII (1996) pp. 177-195; J. MoLINA, Gli artisti del re nel Trecento Aragonese, en "Annali della Classe di Lettere e Filosofia" 12 (Atti del Convengo L'artista medievale, Modena, 1999), en prensa. La aparición y desarrollo del retrato autónomo en los ámbitos cortesanos de en torno 1300 ha sido objeto de diferentes aproximaciones. Para la escultura vid. R. RECHT, Le portrait et le principe de realité dans la sculpture: Philippe le Bel et l'image royale, en Europaïsche Kunst um 1300. Akten des XXV International Kongresses für Kunstgeschichte, 6, Viena, 1986, 189-201. Desde una perspectiva más general, A. MARTINDALE, Heroes, ancestors, relatives and the birth of the portrait, Groningen 1988, pp. 19-20; M WARNCKE, L'artiste et la cour. Aux origines de l'artiste moderne, París, 1989, pp. 262-277.

${ }^{12}$ Vid. Bracons, Operibus, op. cit., passim.
}

«Anuario de Estudios Medievales», 34/1 (2004), pp. 417- 454.- ISSN 0066-5061. 
tiempo atrás ${ }^{13}$. Por otra parte, en relación con las interesantes particularidades iconográficas que presenta la efigie, a las variantes que convierten a esta imagen en un auténtico unicum en el terreno de la representaciones carolinas, debemos tener en cuenta diversos aspectos. Uno realmente importante es el prestigio obtenido por Carlomagno en los territorios de la Marca Hispánica en virtud de la legendaria creencia de que él había sido el fundador de los condados catalanes ${ }^{14}$. La existencia de tal idea, que puede reseguirse en una serie de crónicas autóctonas, justifica por sí misma la realización de una imagen del emperador de acuerdo con los cánones iconográficos de los monarcas catalano-aragoneses: ya que se trataba del artífice de la sucesión de condes y reyes de la casa de Barcelona resultaría lícito representarlo con sus propios atributos. Otra posibilidad, probablemente mucho más plausible, nos remite al uso del principio de disyunción. Es decir, que el autor de la escultura -Jaume Cascalls o alguien próximo a él- recurriera a la aplicación de modelos de la iconografía áulica autóctona porque desconociera los prototipos de la iconografía imperial o, sencillamente, porque quisiera hacer reconocible la imagen del emperador, de un poderoso al fin y al cabo, mediante el uso de una serie de fórmulas convencionales inteligibles para todos los espectadores trecentistas ${ }^{15}$. Del mismo modo cabe suponer que la excepcional representación de Carlomagno sobre una serie de bestias monstruosas, cual verdadero alter ego del Cristus victor, constituye un intento de evocar su vertiente de héroe del cristianismo favorecido por las fuerzas celestiales en su lucha contra los infieles. De hecho, como podremos comprobar más adelante, esta faceta del emperador franco fue desde antiguo subrayada de manera especialmente enfática en los textos de la llamada leyenda gerundense, donde se narran los hechos maravillosos acaecidos

\footnotetext{
${ }^{13}$ P.C. ClaUSSEN, Ritratto, en Enciclopedia dell'Arte Medievale, vol. X, Roma, 1999, p. 34. Ejemplos paradigmáticos de pseudo retratos son las efigies de los profetas del Arca de los Reyes Magos de Colonia o las imágenes de los donantes de Naumburg. Sobre estos últimos, vid. W. SAUERLANDER, Die Naumburger Stifterfiguren. Rückblick und Fragen, en Die Zeit der Staufer. Geschichte-Kunst-kultur, V, Supl. Vörtrage und Forschungen, cat. Stuttgart, 1979, pp. 169-245.

${ }^{14}$ B. SHOLOD, Charlemagne in Spain, Ginebra, 1966, pp. 198-208; P. FREEDMAN, Cowardice, Heroism and the Legendary Origins of Catalonia, "Past and Present", 121 (1988), pp. 3-28.

${ }^{15}$ Además, la posibilidad de acceder a modelos áulicos era relativamente sencilla y próxima. Recordemos que por las mismas fechas en que era ejecutado el san Carlomagno el escultor Aloi de Montbrai - probablemente con la colaboración del mismo Jaume Cascalls, su socio desde 1347- se ocupaba de realizar en Girona las primeras imágenes para una serie de 19 estatuas de alabastro de los condes y reyes de Barcelona encargadas por Pedro el Ceremonioso. A tenor de su instalación en una especie de tabernáculo construido en el Salón del Tinell del Palacio Real Mayor de Barcelona, es muy probable que dichas esculturas, desgraciadamente perdidas, tuvieran unas dimensiones parecidas a las de la pieza gerundense, con lo que las afinidades se multiplican.

«Anuario de Estudios Medievales», 34/1 (2004), pp. 417- 454.- ISSN 0066-5061.
} 
durante la conquista de la ciudad por parte de Carlomagno y su ejército (apariciones de la Virgen y Santiago, lluvia de sangre durante el sitio o aparición de una gran cruz sobre la mezquita musulmana, entre otros).

La compleja iconografía de la imagen gerundense dedicada a San Carlomagno no es, en cualquier caso, el principal argumento de este estudio. En las próximas páginas nos ocuparemos más bien de analizar los motivos que dieron lugar a su existencia o, lo que es lo mismo, de averiguar las razones que se esconden tras la institucionalización del culto al emperador carolingio en Gerona y las lecturas que se desprenden de tan singular acción.

\section{El RECUERdo de CARlomagno EN LA CATEDRAL}

La historia de cualquier edificio del pasado está siempre teñida de leyendas y anécdotas. La catedral de Gerona no es una excepción, y entre las curiosidades que nos brinda un detenido estudio de su patrimonio monumental se encuentra descubrir la estrecha vinculación que una parte del mismo mantiene con la figura de Carlomagno. La nómina es extensa, e incluye desde construcciones y objetos de época románica - la torre-campanario (fig. 3), la cátedra episcopal, el bordado de la Creación o la imagen de la Virgen con el Niño que durante siglos presidió el altar- hasta otros realizados en fechas más avanzadas - una Biblia boloñesa conservada en el Museo catedralicio, el cartulario, una campana y una desaparecida copa de oro y plata. El nexo común entre todos estos bienes muebles e inmuebles es la costumbre popular de intitularlos con el nombre del emperador franco pese a que, como vemos, se trata de obras realizadas en momentos muy posteriores al período carolingio. Tan anacrónica y sorprendente asociación parece responder a dos motivos básicos. Por un lado, en el caso de la torre-campanario y las piezas románicas revela la voluntad de rendir homenaje a quién, según una serie de antiguas tradiciones apócrifas, era considerado su promotor o donante ${ }^{16}$.

\footnotetext{
${ }^{16}$ Así ocurre, por ejemplo, con la imagen de la Virgen sedente con el Niño, uno de los símbolos de la sede gerundense que aún hoy puede contemplarse en el Museo de la Catedral -eso sí, desprovista del espléndido recubrimiento de plata que en la Edad Media constituía su principal efecto estético. De acuerdo con una inveterada tradición local se trataba de la imagen que Carlomagno llevaba sobre su caballo durante las batallas contra los musulmanes. Vid. E. GIRBAL, Carlomagno en Gerona, "Revista de Gerona", VIII (1884), p. 227, quién de manera más sucinta también hace referencia a otras piezas relacionadas con el emperador. Respecto a la atribución del bordado de la Creación, vid. L. BATLlE, El viaje de Carlos Va Gerona en 1538, "Hispania". XXXIV (1949) p. 20, 30-31. Para el caso de la Biblia boloñesa, F. MERINO y J. LA CANAL, España Sagrada, XLIII, Madrid, 1819, p. 77. Con relación al cartulario, J. MARQUĖS 
Desde una perspectiva más general la utilización del apelativo expresa el deseo de preservar el recuerdo de un personaje que a lo largo de toda la Edad Media gozó de gran renombre entre los gerundenses y, de manera especial, entre los eclesiásticos de la catedral. De este modo lo sucedido en la ciudad del Onyar señala uno de los capítulos más significativos del amplio y dilatado proceso de mitificación de que fue objeto la figura de Carlomagno en la Cataluña medieval, un fenómeno que conoció expresiones tanto en el terreno de la historiografía como en el campo de la toponimia ${ }^{17}$.

El origen y, al mismo tiempo, la manifestación más paradigmática del prestigio de Carlomagno en Gerona es la leyenda que narra la historia de su conquista de la ciudad y fundación de la sede episcopal. Construido a partir de la fusión de materiales de carácter local con otros extraídos del PseudoFilomena y el Pseudo-Turpín, el relato ha llegado hasta hoy a través de diversas versiones muy próximas entre sí teniendo en cuenta que se trata de textos redactados en un arco de tiempo de cinco siglos, lo cual hace inevitable la existencia de numerosas variantes en forma de añadidos y omisiones $^{18}$.

PlanagumÀ, Cartoral, dit de Carlemany, del Bisbe de Girona: s. IX-XIV, Barcelona, 1993, I, p. 12. Como veremos más adelante, es muy posible que la legendaria creencia en la participación de Carlomagno en el proceso de construcción y decoración de la catedral románica tomara cuerpo a inicios del siglo XIV, puesto que fue por entonces cuando surgieron una serie de textos en los que se establece una relación personal entre el emperador franco y algunos distinguidos promotores históricos del templo consagrado en el año 1038.

${ }^{17}$ Recientemente el tema ha sido objeto de estudio en dos sugerentes y informativos trabajos. Vid. N. JASPERT, Historiografía y legitimación carolingia. El monasterio de Ripoll, el pseudoTurpín y los condes de Barcelona en El pseudo-Turpín. Lazo entre el culto jacobeo y el culto de Carlomagno ("Actas del VI Congreso Internacional de Estudios Jacobeos"), Santiago, 2003, pp. 297-315 y, sobre todo, ID., ¿Dos cultos relacionados? Santiago y Carlomagno en la Cataluña medieval en El Camí de Sant Jaume $i$ Catalunya. Història, Art i Cultura del Camí (Barcelona, Cervera, Lleida 2003) en prensa. A partir de un hecho tan significativo como fue la copia del Pseudo-Turpín realizada el año 1172 o 1173 en Santiago de Compostela por Arnaldo de Monte, monje del monasterio de Ripoll, Jaspert reconstruye la larga vigencia del mito de Carlomagno en la Cataluña medieval y su frecuente utilización-manipulación para conceder legitimidad y prestigio a diversos sujetos, desde la casa condal barcelonesa hasta establecimientos monásticos. Agradezco a Nikolas Jaspert su amabilidad por permitirme consultar el texto de su artículo antes de su publicación. Napoli nel cuore.

${ }^{18}$ En la catedral de Gerona se conservan tres importantes textos sobre la leyenda de Carlomagno: se trata de dos oficios religiosos titulados Officium in festo sancti Caroli Magni imperatoris et confessioris, ambos redactados a mediados del siglo XIV, y del Tractatus de captione Gerunde et edificatione ipsius cathedralis ecclesie et quomodo beatus Karolus Magnus imperator eamdem dotavit atque in ea episcopum ordinavit, escrito a finales del siglo XV. Para un detallado estudio de estos y otros testimonios literarios del relato y de sus fuentes inspiradoras, Vid. J.G. RoIG I JALPÍ, Carta apologética por la entrada de Carlos el Grande en Cataluña, Barcelona, 1678; J. CoulEZ, Étude sur l'office de Girone en l'honneur de Saint Charlemagne, Montpellier, 1907, pp. 20-28, 70-159; B. SHOLOD, Charlemagne in Spain, Ginebra, 1966, pp. 198-208; M. COll i AlENTORN, La llegenda de Carlemany a Girona, en Llegendari, BarcelonaAbadia de Montserrat, 1993, pp. 157-161; G. RoURA, L'ofici de Sant Carlemany al bisbat de Girona, "Miscel-lània Litúrgica Catalana", IV (1990), pp. 42-43, 50-54; J. CLARÀ, L'ofici a 
Ensayaremos aquí una abreviada exposición que reúna los principales acontecimientos que componen el relato legendario.

Las milagrosas apariciones de Santiago, San Andrés y la Virgen son el punto de partida. A través de ellas los personajes celestiales invitan a Carlomagno a cruzar los Pirineos para luchar contra los musulmanes y conquistar Gerona, donde se le conmina a construir una gran iglesia catedral. De inmediato el emperador reúne su ejército e inicia la campaña en el Rosellón. En un lugar cercano a Elna obtiene su primera victoria, tras la cual decide fundar el monasterio de san Andrés de Sureda. Una vez cruzadas las montañas y ya en territorio hispano se reproducen las escaramuzas, naturalmente siempre con resultado favorable a los cristianos. Un hecho a destacar es que, paralelamente a las acciones militares, Carlomagno despliega una intensa actividad como fundador de templos. Buena prueba de ello es su patronazgo sobre las iglesias de Sant Martí de Forndelvidre, Sant Julià de Ramis y el monasterio de Santa María de Amer. Finalmente, tras una maniobra envolvente, pone sitio a la ciudad de Gerona, momento en el que comienzan a desencadenarse los episodios más maravillosos de leyenda. La historia cuenta que todos los intentos para tomar la ciudad fracasaron hasta que un día, un viernes según algunas versiones, apareció sobre la mezquita, situada en el lugar donde hoy se levanta la catedral, una gran cruz luminosa de color rojo. De la misma caían unas gotas de sangre que, al tocar el suelo, se transformaban en pequeñas cruces. La visión y la milagrosa lluvia eran el anuncio de la inminente derrota de los enemigos de la fe, quienes, poco después, emprendieron la huída en desbandada no sin antes haber sufrido los estragos de una peste. Fue entonces cuando el emperador hizo su solemne entrada en la ciudad en medio del entusiasmo de sus habitantes. El relato concluye con la fundación de la catedral dedicada a la Virgen María, a la que Carlomagno dotó con toda clase de presentes y en la que ordenó levantar un altar de la Santa Cruz en memoria de la señal celeste que había precedido la toma de la ciudad. Se completaba de esta forma una particular narración muy alejada de los acontecimientos históricos que en realidad sucedieron durante la conquista de Gerona por las tropas carolingias el año 785, una aventura militar que supuso el primer paso para la configuración de la Marca Hispánica

Carlemany dins el Breviari de 1339, "Annals de l'Institut d'Estudis Gironins", XXXIV (1994), pp. 619-628.

«Anuario de Estudios Medievales», 34/1 (2004), pp. 417- 454.- ISSN 0066-5061. 
y en la que sabemos que el emperador no tomó parte ${ }^{19}$. Da lo mismo. Durante siglos el relato mítico y maravilloso ocupó un destacado lugar en el imaginario colectivo de los gerundenses, convirtiéndose en la versión de los hechos que gozó de mayor predicamento a nivel popular ${ }^{20}$.

Hasta hoy el testimonio más antiguo conocido de este relato legendario es el texto de una crónica del monasterio de Ripoll, llamada el Rivipullense, fechada a mediados del siglo $\mathrm{XI}^{21}$. Al margen de certificar que nos hallamos ante una de las versiones literarias más precoces sobre los orígenes de la Marca Hispánica, la cronología del relato rivipullense abre la posibilidad de establecer una conexión entre la difusión de la leyenda y la promoción de determinados cultos, espacios y obras de la catedral de Gerona durante el periodo románico; es decir, nos permite suponer la existencia una temprana e importante influencia de la fabulosa tradición sobre la realidad monumental y litúrgica de la sede episcopal. Al menos esto es lo que parece deducirse de la especial veneración que se tributó al símbolo más emblemático de la leyenda: la Santa Cruz. Recordemos que fue precisamente a finales del siglo XI o inicios del XII cuando se dedicó a este signo cristológico el altar principal del Santo Sepulcro, el gran cuerpo occidental construido poco después de la primera cruzada. Mencionado ya en 1106, el altar de la Santa Cruz era el lugar donde hallaban depositadas las reliquias más importantes de la catedral, entre ellas la Vera Cruz y la Santa Espina, circunstancia que hizo de él un espacio absolutamente privilegiado en el marco de la topografía

${ }^{19} \mathrm{El}$ análisis histórico de la campaña carolingia que logró conquistar Gerona es la materia principal del libro Girona dins la formació de l'Europa Medieval 785-1213 (catálogo de exposición, 22 junio-23 noviembre de 1985), Girona 1985.

${ }^{20}$ Lo certifica la vigencia de la leyenda a inicios del siglo XX. J. AMADES, Folklore de Catalunya: Rondallística, Rondalles, tradicions i llegendes, Barcelona, 1950, p. 1151.

${ }^{21}$ Chronicon alterum Rivipullense. Vid. J. VILlanUEVA, Viaje literario a las iglesias aie España, Vol. V, Madrid 1806, 242-243, donde leemos que el año 785 "Gerundam civitatem homines tradiderunt regi Karolo. Et multi viderunt sanguinem pluere: el mortalitas magna secuta. Apparuerunt acies in celo et signum $\dagger$ in vestimentis hominum". Consultese asimismo, $E l$ Scriptorium de Ripoll, en "Catalonia Monastica, Recull de documents i estudis referents a monestirs catalans", I (1927-29), pp. 23-96. El texto es objeto de interesantes comentarios en M. COLl i AlENTORN, La llegenda d'Otger Cataló $i$ els nous barons, en Llegendari BarcelonaAbadia de Montserrat, 1993, p. 8 y SHOLOD, Charlemagne, ob.cit., p. 199. Otras referencias antiguas a la conquista de Gerona por Carlomagno se encuentran en el fragmento de la Haya, la Chançun de Guillelme, la Crónica de Moissac y la Primera Crónica de General de Alfonso X el Sabio. COULET, Etude sur l'office, ob. cit., pp. 8-13, 117-132; COLl I AlENTORN, La llegenda de Carlemany, ob. cit. pp. 152-153. 
templaria ${ }^{22}$. Una relevancia semejante a la que, según la leyenda, Carlomagno otorgó a la fundación que promovió en honor a idéntico culto. Señalemos además que, del mismo modo que en el relato fantástico se cuenta que el emperador quiso que el altar de la Santa Cruz fuera levantado encima del altar mayor dedicado a la Virgen, o sea en un lugar elevado, los documentos indican que el altar del Santo Sepulcro se encontraba emplazado en un piso superior. En resumen, que los paralelismos entre la leyenda y el espacio cultual concebido en época románica parecen ir mucho más allá de la simple coincidencia de advocaciones ${ }^{23}$.

También elocuente de lo que aquí tratamos de exponer es la iconografía de una de las piezas más emblemáticas del período: el bordado de la Creación. La historia de la invención de la Santa Cruz constituye uno de los motivos principales del complejo programa reproducido en esta obra, probablemente tejida durante la segunda mitad del siglo $\mathrm{X}^{24}$. Gracias a dicha particularidad en alguna ocasión ya se apuntó la posible relación del bordado con el altar del Santo Sepulcro antes mencionado y la hipótesis que hubiera sido concebido para ocupar un lugar preeminente en él mismo ${ }^{25}$. Al margen de la verosimilitud de estas propuestas, puesta en duda en los últimos estudios dedicados a la pieza ${ }^{26}$, es muy posible que una de las claves para desentrañar el origen del ciclo de imágenes dedicado a la Santa Cruz sea la marcada exaltación que se hace de este símbolo cristológico en la leyenda de Carlomagno así como su relación con los orígenes de la catedral. La misma

${ }^{22} \mathrm{~J}$. MARQuÉs CASANOvAS, La fachada de la catedral de Gerona, "Anales del Instituto de Estudios Gerundenses" X (1965), pp. 290-291; F. EsPAÑOL, Massifs occidentaux dans l'architecture romane catalane, "Les Cahiers de Saint-Michel de Cuxa", XXVII (1996), pp. 7374.

${ }^{23}$ Otra manifestación del arraigo del culto a la Santa Cruz en la catedral gerundense es la reliquia que se encontraba oculta en el cenotafio del altar mayor, descubierta el 13 de febrero de 1347 durante el traslado del ara románica al nuevo presbiterio gótico. Se trataba de una "crux cum laminibus argenteis munita et cohoperta, que de cruce christi verosimiliter presumebatur". F. FitA, Los Reys de Aragó y la Seu de Girona, Barcelona, 1873, p. 106.

${ }^{24} \mathrm{P}$. PALOL, El tapís de la Creació de la catedral de Girona, Barcelona, 1986, pp. 127-133. Recientemente se ha publicado un estudio monográfico sobre el ciclo de la Santa Cruz cuya principal y discutible tesis es la propuesta de una lectura de las imágenes a partir del contexto de celebración de la reconquista en los territorios de la Marca Hispánica, y en concreto en el condado de Barcelona. La propuesta es que nos hallamos ante un "mirror for the royal houses of northern Spain". B. BAERT, New observations of the Genesis of Girona (1050-1100). The Iconography of the Legend of the True Cross, "Gesta", XXXVIII/2 (1999), pp. 124-125.

${ }^{25}$ J. MARQués CASANOvas, El tapís de la Creació en el seu context, "Revista de Girona", 92 (1980), p. 218ss. También se hace eco de dicha idea PALOL, El tapís, op. cit., 156.

${ }^{26} \mathrm{M}$. CASTIÑEIRAS, Viejas y nuevas cuestiones en torno al Bordado de la Creación de Girona, "Annals de l'Institut d'Estudis Gironins", XXXV (1995), pp. 97-122.

«Anuario de Estudios Medievales», 34/1 (2004), pp. 417- 454.- ISSN 0066-5061. 
incidencia iconográfica en el protagonismo de Constantino o Heraclio otorga a los episodios descritos en el bordado un inequívoco tono de exaltación imperial que no podemos obviar desde el momento que evoca el recuerdo de personajes considerados prefiguras del propio Carlomagno. Naturalmente uno podría pensar que se trata de argumentos demasiados endebles para apoyar nuestra tesis. Y estará en lo cierto: no disponemos de pruebas suficientes como para asegurar de manera rotunda que quienes proyectaron el ciclo de imágenes de la Santa Cruz actuaron influidos en mayor o menor medida por la leyenda de Carlomagno. Sin embargo, a tenor de la más que probable difusión de esta fantástica historia entre los gerundenses, aquello que parece fuera de toda duda es que de alguna manera u otra la asociación entre el relato y las imágenes se acabaría imponiendo como algo inevitable entre los espectadores del bordado.

El proceso de consolidación de la leyenda en la memoria colectiva y, en concreto, en el imaginario de la catedral conoció un innegable impulso a partir de la decisión del prelado Arnau de Montrodon de instituir la fiesta de San Carlomagno en la sede episcopal, su diócesis y en todos los monasterios benedictinos de la misma. Mediante un decreto se estableció que la celebración de los oficios litúrgicos, la lectura de un sermón y una solemne procesión en honor del nuevo santo tuviera lugar cada 28 de enero ${ }^{27}$. Corría el año 1345 , y con este gesto absolutamente excepcional en el ámbito hispano, donde la figura del emperador carolingio nunca dio lugar a tan grandilocuentes manifestaciones de carácter cultual, se materializó en Gerona el ascenso a los altares de un personaje venerado por su doble condición de liberador de la ciudad y fundador de la catedral ${ }^{28}$. Algunos años antes que esto sucediera, la

\footnotetext{
${ }^{27}$ El texto del decreto fue copiado en el Libro de Privilegios segundo o menor y Concordias, 1606, Girona, Arxiu Capitular de la Catedral, fols. 8-10. Su contenido es objeto de comentarios por parte de P. ROCHER, Les rapports de l'église de Puy avec la ville de Girone en Espagne et le Comté de Bigorre, Le Puy, 1875, pp. 261-267; COULET, Études, p. 25ss.; ROURA, L'ofici, p. $42-44$.

${ }^{28} \mathrm{La}$ fiesta en honor a San Carlomagno se celebró hasta 1484 , momento en que fue prohibida por orden de Sixto IV. CoulEZ, Etude, p. 30; RouRA, L'ofici, p. 48. Esta circunstancia no supuso, ni mucho menos, que se suprimiera la práctica de las manifestaciones devotas. Durante siglos el cabildo de la catedral siguió tributando un especial homenaje al emperador carolingio mediante la lectura de un sermón en el que se recogían los principales acontecimientos de la leyenda. El texto sería semejante al Tractatus de captione Gerunde, una pieza redactada precisamente en torno a 1484 donde se concede una especial relevancia a los episodios de la fundación de la catedral y el altar de Santa Cruz. Vid. COULET, Études, pp. 70-116, con edición del texto, pp. 77-82; SHOLOD, Charlemagne, pp. 204-205; Coll, La llegenda, pp. 159-161. El grandilocuente tono del panegírico sorprendió al padre Villanueva, quién aún pudo escucharlo a inicios del siglo XIX durante su visita a la catedral gerundense: "El sermón que yo oí este año 1807 me parece muy ajeno del espíritu de la Iglesia, que tolera se haga un recuerdo fúnebre de

«Anuario de Estudios Medievales», 34/1 (2004), pp. 417- 454.- ISSN 0066-5061.
} 
acción de Carlomagno de promover y dedicar este templo a la Virgen ya había dado lugar a la constitución de la cofradía de Santa María, encargada de honrar el recuerdo del emperador en la sede gerundens $\mathrm{e}^{29}$. Desde el preciso instante que alcanzó la dignidad episcopal Arnau de Montrodon impulsó, mediante la concesión de beneficios y prerrogativas, el desarrollo de esta institución devota con el objetivo de hacer de ella uno de los garantes del nuevo culto.

Si bien resulta obvio que en Gerona la leyenda local constituyó el fundamento básico para la instauración de la fiesta también existe la posibilidad de ver en este hecho el eco de una práctica muy extendida en los dominios del Sacro Imperio Germánico ${ }^{30}$. El análisis de la historia de la devoción al emperador en los territorios del centro y norte de Europa permite constatar que fue precisamente a lo largo del primer tercio del siglo XIV, y en especial a partir de 1330, cuando quedaron definidos plenamente los usos y oficios litúrgicos necesarios para celebrar el culto a San Carlomagno ${ }^{31}$. La coincidencia cronológica entre este proceso desarrollado en diversas sedes episcopales septentrionales y la oficialización del culto en Gerona no parece ser casual. Es bien sabido que durante su larga etapa como canónigo de la catedral Arnau de Montrodon realizó varios viajes a Bolonia, Roma y

este héroe, más no un elogio cual se hiciera venerándolo en los altares". VILLANUEVA, Viaje literario, XII, 198-200. Aunque desconocemos la fecha exacta que dejó de recitarse todo parece indicar que fue un poco antes de 1883. Así parece deducirse de la ausencia de cualquier tipo de referencia al sermón en el decreto que ese mismo año dictó el obispo Tomás Sivilla, y en el que ordena retirar la imagen de alabastro de San Carlomagno que hasta entonces se hallaba expuesta en la Capilla de los Cuatro Santos Mártires. Para la orden episcopal, vid. RourA, L'ofici, p. 49.

${ }^{29} \mathrm{La}$ cofradía existía desde mucho antes que se instituyera la fiesta a Carlomagno, y ya en el año 1313 el obispo Pere de Rocabertí le concedía una licencia para construir una capilla en la nueva cabecera gótica de la catedral que por aquel entonces se empezaba a edificar. RoURA, L'ofici, p. 44.

${ }^{30} \mathrm{~A}$ finales del siglo XIX Fidel Fita ya señalaba que la introducción de la fiesta en Gerona se produjo "com aleshores era costum general de les Seus de Bèlgica i Alemania". FITA, La catedral, p. 47.

${ }^{31} \mathrm{R}$. Folz, Études sur le culte liturgique de Charlemagne dans les églises de l'Empire, Estrasburgo, 1951, p. 6-11. Carlomagno fue canonizado el año 1165 por el antipapa Pascual III, que actuó a instancias del emperador Federico I Barbarroja. La decisión, de clara naturaleza política, debe interpretarse como un capítulo más del enfrentamiento que mantuvieron el Papado y el Imperio entre los siglos XI-XIII. Desde el partido gibelino se fomentó una visión mítica y legendaria de Carlomagno, convirtiéndolo en un campeôn de la fe cristiana, un héroe protegido por las fuerzas celestiales en su infatigable y victoriosa lucha contra los infieles. Como cabía esperar su culto se difundió por numerosas sedes episcopales del Imperio desde el primer cuarto del siglo XIII hasta mediados del XIV - en Francia, por ejemplo, hubo que esperar hasta el reinado de Carlos V. Los motivos eran diversos en cada caso: la asociación del emperador con santos locales, su prestigio como fundador de iglesias, la influencia de la doctrina de los Staufen etc. Estas y otras cuestiones relacionadas con el culto imperial son diseccionadas en el citado estudio de Folz. 
Aviñón $\mathrm{n}^{32}$, una experiencia cosmopolita que sin lugar a dudas le permitió observar y conocer otros rituales de complejo universo litúrgico cristiano. Teniendo en cuenta que procedía de un lugar donde la figura de Carlomagno seguía viva merced a la persistencia y vitalidad de una leyenda local ¿Cabe dudar de su interés por obtener información sobre las costumbres desarrolladas en otros centros donde el culto al emperador era practicado desde hacia más de un siglo y medio? Desconocemos de qué manera y quien los transportó hasta Gerona, pero lo cierto es que en su catedral aún hoy se conservan unos oficios litúrgicos de la fiesta de Carlomagno semejantes a los redactados en Zurich y Halderstadt a comienzos del siglo XIV ${ }^{33}$. Ello revela el conocimiento de las fórmulas aplicadas en lugares muy distantes, e incluso sugiere la posibilidad que fueran utilizadas como modelos para la compilación de unos nuevos oficios gestados de acuerdo con las tradiciones autóctonas.

En cualquier caso, y a diferencia de los textos de origen septentrional conservados en la catedral, en los que nada se dice de la aventura de Carlomagno en tierras gerundenses, el Officium in festo Sancti Caroli Magni imperatoris et confessionis, la pieza central de la celebración de la fiesta en la sede gobernada por Arnau de Montrodon, fue compuesta en torno a 1345 a partir de materiales procedentes de la leyenda loca ${ }^{34}$. A través de sus 9 lecciones se hace referencia al papel desempeñado por el emperador en la construcción de diferentes templos gerundenses así como a los hechos maravillosos acaecidos antes de su entrada en la capital. Y pese a que en su inicio se señala cuales son los principales objetivos de la cruzada resulta cuando menos extraño constatar la falta de una mención explícita a la toma de la ciudad y la posterior fundación de la catedral. Es probable que la omisión de tan destacados episodios quedase subsanada mediante su inclusión en el sermón que, junto a una misa, sabemos que era pronunciado la tarde de cada 29 de enero.

\footnotetext{
${ }^{32}$ A. PladeVAll, Arnau i Bertran de Montrodon, dos grans bisbes del segle XVI, "Annals de l'Institut d'Estudis Gironins", XXXIV (1994), p. 407; ID., Montrodon, Passat i present d'un gran llinatge $i$ d'un casal osonenc, Vic, 2001, p. 115.

${ }^{33}$ Coulet, Étude, pp. 45, 117-118; SHolod, Charlemagne, p. 201.

${ }^{34} \mathrm{Se}$ trata del oficio recitado en vespres y laudes. En el momento de su redacción el texto original fue incorporado en el Breviarium Gerunden de anno 1339, Girona, Arxiu Capitular de la Catedral, Ms. 98, fols. DCLIX-DCLX. Para su transcripción y estudio, vid. MERINO-LA CANAL, España Sagrada, XLIII, pp. 512-514; VILlANUEVA, Viaje, XIV, pp. 267-269; CoULET, Études, pp. 117-159; ClarÀ, L'ofici, pp. 619-629, con edición del oficio en pp. 624-628.

«Anuario de Estudios Medievales», 34/1 (2004), pp. 417- 454.- ISSN 0066-5061.
} 
El epicentro del nuevo culto fue la capilla de los Cuatro Santos Mártires, la primera de la cabecera gótica por el lado del Evangelio. La elección de este espacio resultaba lógica si tenemos en cuenta dos factores. El primero, de carácter estrictamente personal, tiene que ver con el hecho que se trata de una capilla edificada y decorada a expensas de Arnau de Montrodon quién, al igual que otras importantes dignidades del cabildo catedralicio, contribuyó de este modo a la materialización de la nueva cabecera gótica ${ }^{35}$. Concebida inicialmente como ámbito para la veneración de los mártires gerundenses, la construcción no sólo albergó el culto a San Carlomagno sino que, tiempo más tarde, también acogió los sepulcros monumentales de Arnau y su sobrino Bertran (fig. 4) ${ }^{36}$. Es decir, en menos de medio siglo se transformó en el escenario de una grandilocuente proyección del linaje de los Montrodon y de los cultos autóctonos que auspiciaron; en la monumental expresión de una política religiosa que, a nadie se le escapa, era fruto de tanto de un sentimiento devocional como del deseo de concretar referentes de prestigio y autoridad para los promotores de la capilla. En otro orden de cosas, apuntemos que el propio Arnau se encargó de fomentar una relación "histórica" entre Carlomagno y los Cuatro Santos Mártires. Al menos ello es lo que se deduce de la lectura del oficio litúrgico que compuso para éstos últimos, y en el que podemos leer que fue precisamente Carlomagno quién descubrió los restos de los mártires en la iglesia suburbana de San Félix y quién más tarde los depositó en el altar mayor de la catedra ${ }^{37}$. Ante dicha

\footnotetext{
${ }^{35}$ Diversos indicios apuntan a que la construcción se llevó a cabo con notable celeridad entre 1312 y 1320, es decir, unos años antes de lo que se ha venido suponiendo hasta hoy en día. F. ESPANNoL, L'escultor Joan de Tournai a Catalunya, "Annals de l'institut d'Estudis Gironins", XXXIII (1994), p. 105. La hipótesis tradicional situaba el comienzo de la construcción en torno a 1330. Vid. PladeVAll, Arnau $i$ Bertran, pp. 402-403. Sin embargo una noticia fechada ese mismo año señala que Arnau de Montrodon ya había "construxit in opere novo capitis jamdicte Ecclesie Gerundensis quandam Capellam et altarem in honorem et subinvocacione beatorum martirum Germani, Justuri, Paulini et Sicii". FITA, Los Reys, p. 105.

${ }^{36}$ Sobre la labor promotora de Bertran de Montrodon, artífice del conjunto funerario, consúltese el magnífico trabajo de F. EsPAÑoL, Joan Avesta, p. 385.

37 “Beatus Karolus Magnus imperator et rex Francie cepit civitatem Gerunde fecitque novam sedem in mesquita agarenoirum. Revelatoque sibi quod quator martyres fuerunt sepulti in dicta ecclesia, maximo cum honore transtulit eos ad altare beate Marie". G. RouRA, El culte als quatre sants màrtirs de Girona, "Analecta Sacra Tarraconensia", 71 (1998), pp. 711-719. Observemos que en este texto, probablemente redactado en torno a 1336, fecha de la institución de la fiesta a los Cuatro Mártires, Carlomagno es de nuevo presentado en su faceta de liberador de la ciudad y fundador de la sede episcopal. Ello demuestra no sólo el arraigo de la leyenda del emperador entre los eclesiásticos de la catedral sino también una suerte de mistificación hagiográfica, resultado de la introducción del relato fantástico en las vidas de santos locales. Es posible que con ello se buscara otorgar mayor autoridad a la leyenda imperial y, de paso, construir una homogénea e integrada versión de la literatura sagrada local.
} 
circunstancia ¿Qué mejor lugar para celebrar el culto a San Carlomagno que la capilla donde reposaban unos sagrados cuerpos recuperados gracias a su celo cristiano?

Además de la redacción de un oficio litúrgico y de la elección de un ámbito apropiado para su celebración otra de las consecuencias directas del establecimiento de la fiesta a San Carlomagno fue la promoción de imágenes que hicieran posible la visibilidad del nuevo culto. Naturalmente la más emblemática de todas ellas es la escultura de alabastro de San Carlomagno que hemos analizado en la primera parte de nuestro ensayo y que, a buen seguro, fue concebida para que presidiera las ceremonias dedicadas al emperador. Conservamos, asimismo, otra obra que presenta una interesante visión sintética de los acontecimientos comentados hasta el momento. Nos referimos a la monumental cátedra episcopal de madera que hoy se expone en la capilla del Santísimo Sacramento (fig. 5). La obra fue contratada por el maestro Aloi de Montbrai en 1351, tres años después de la muerte del obispo Arnau de Montrodon $^{38}$. Pese a esta circunstancia la participación en el proyecto del prelado o de su sobrino Bertran, por aquel entonces canónigo de la catedral, se antoja indudable al comprobar un revelador detalle: los escudos de la familia Montrodon que campean por toda la amplia superficie del respaldo, una elocuente alusión al linaje del promotor o promotores de la obra. Es evidente que si éste fue Arnau nos encontramos ante una pieza ejecutada para cumplir los deseos del obispo recientemente fallecido o ante un homenaje postmortem de su persona. En cualquier caso, la vinculación de la cátedra episcopal con los Montrodon ofrece la clave para interpretar el sentido último de las imágenes de bulto redondo instaladas en los laterales: a la izquierda, la figura de un obispo arrodillado ante un monarca que luce los atributos propios de los reyes catalano-aragoneses; a la derecha, una composición simétrica protagonizada por un acólito frente a la imagen de la Virgen. Con lo apuntado hasta aquí, disponemos de los argumentos suficientes para suponer que la idea fundamental que nos transmite este pequeño conjunto de imágenes es la de rendir homenaje tanto a Carlomagno, el fundador de la catedral y responsable de su dedicación a la Virgen, aquí de nuevo representado bajo la apariencia

\footnotetext{
${ }^{38}$ La noticia y transcripción del contrato la debemos a FiTA, Los Reys, pp. 106-107. Para la discusión en torno a la autoría y cronología de la obra, vid. FREIXAS, L'art gòtic, pp. 115-116 y F. ESPAÑol, Los membra disjecta de un coro gótico catalán en el Museo de Cleveland, Imágenes y promotores en el arte medieval, "Miscelânea en homenaje a Joaquín Yarza Luaces", Bellaterra, 2001, pp. 337-352, donde se apunta la interesante noticia de la conservación de importantes restos de la sillería de coro gerundense en una colección particular de La Garriga (Barcelona). 
de un monarca catalano-aragonés, como a Arnau de Montrodon, el obispo que aparece a sus pies y que tan decisivo papel desempeñó en la promoción del culto al emperador carolingio. En resumen, en uno de los muebles más emblemáticos de la sede episcopal se representó un pequeño programa concebido para proyectar a la posteridad el recuerdo de la leyenda y de su más ferviente impulsor.

\section{Claves y lecturas de Un CUlto}

Tras constatar la persistencia de la memoria de Carlomagno en la sede gerundense desde al menos el siglo XI y su fuerte impronta en el imaginario colectivo debemos procurar discernir cuales fueron las razones que impulsaron al obispo Arnau de Montrodon a instaurar una celebración litúrgica en honor del emperador carolingio, a elevar la leyenda a la categoría de culto. Se trata, en definitiva, de responder a dos preguntas cruciales que hasta hoy no se han formulado los historiadores que han abordado el tema: ¿Por qué el decreto de celebración de la fiesta se promulgó en 1345 y no antes o después? y ¿Qué sentido o sentidos tuvo este hecho para los hombres de mediados del siglo XIV? Podemos ofrecer una rápida respuesta a tales cuestiones aduciendo el carácter estrictamente personal de la acción, afirmando que nos hallamos ante un gesto motivado por la particular atracción que sentía el Arnau de Montrodon hacia la leyenda de Carlomagno ${ }^{39}$. Disponemos de pruebas que avalan dicha idea: desde la voluntad del prelado de establecer el nuevo culto en su propia capilla hasta la decisión, tomada en 1346, de fundar y dotar un beneficio eclesiástico en una capilla de la iglesia de Rupià dedicado a la

${ }^{39}$ De manera explícita o implícita esta es la posición adoptada en la mayoría de estudios dedicados al tema. Una de las escasas excepciones es el interesante pero al mismo tiempo fallido ensayo de Maravall, donde se plantea la posibilidad de interpretar la instauración del oficio de San Carlomagno como una expresión del sentimiento gibelino de Arnau de Montrodon. Vid. J.A. MARAVALL, El culto de Carlomagno en Gerona. La significación histórico-política, "Clavileño" 26 (1954) 19-22 (más tarde integrado en ID., Estudios de Historia del Pensamiento Español. Edad Media, Madrid, 1967, pp. 411-419). Cabe elogiar el intento de proponer una explicación plausible a un acto tan singular y aislado como el que aquí nos ocupa. Sin embargo también es cierto que la hipótesis de Maravall resulta absolutamente genérica e inconcreta por carecer de apoyos documentales o históricos sólidos que la avalen. Destaquemos, además, su total desconocimiento de la leyenda gerundense así como de las tradiciones y acontecimientos que se sucedieron en la catedral a lo largo de la primera mitad del siglo XIV. En el momento de redactar estas líneas aún se encuentra en prensa el citado estudio de Jaspert (;Dos cultos relacionados? op. cit), en el que se apuntan brevemente algunas interpretaciones más verosímiles para explicar la acción del prelado gerundense. Algunas de ellas junto a otras de nuevas serán desarrolladas en este estudio.

«Anuario de Estudios Medievales», 34/1 (2004), pp. 417- 454.- ISSN 0066-5061. 
Santísima Corona de Jesucristo y a Sant Carlemany confessor ${ }^{40}$. Igualmente podríamos mencionar la notable afición de Arnau por la historia, una inclinación que incluso le llevó a recopilar diversas crónicas y tratados conservados en el Archivo Real ${ }^{41}$. Sin embargo, y aún reconociendo la importancia de los argumentos de carácter particular a la hora de explicar la promoción del culto imperial, es muy factible que con su acción en este terreno también persiguiera satisfacer aspiraciones de otra naturaleza. Es bien sabido que en la Edad Media la inclinación personal de los eclesiásticos fue tan sólo uno de los muchos motores que alimentaron la instauración de un culto religioso. Ello resulta más evidente, si cabe, cuando el sujeto venerado era un personaje poderoso que gozaba de gran prestigio gracias a sus vínculos con la historia, real o legendaria, de un territorio. En la mayoría de estos casos se impone valorar en que medida existió una instrumentalización del santo como fuente de legitimación y autoridad de una institución u organismo. Un detenido análisis de los principales hechos que marcaron la vida de la catedral durante la larga permanencia de Arnau de Montrodon en la misma -primero en calidad de canónigo (1297-1335) y después como obispo hasta el año 1348- nos permitirán comprobar que la promoción de determinados cultos, y en concreto el dedicado a San Carlomagno, sólo adquiere todo su sentido si se contempla a la luz de un auténtico programa de exaltación ideológica y simbólica de la sede gerundense.

La simple contextualización del acontecimiento que nos ocupa permite constatar una significativa coincidencia cronológica: la instauración del culto a Carlomagno fue coetánea a la conclusión de las obras de la cabecera gótica de la catedral, iniciadas en 1312. Efectivamente, con la solemnidad característica de estos actos, el 12 de marzo de 1347 el arzobispo de Tarragona,

${ }^{40}$ Roura, L'ofici, p. 45; Pladevall, Montrodon, pp. 118-119. La estrecha relación de Arnau de Montrodon con la localidad ampurdanesa de Rupià, propiedad de la mitra de Gerona, se remonta a su época de canónigo cuando, en calidad de administrador episcopal, se encargó de ampliar sus dominios y de acondicionar el castillo que domina la población como residencia estacional del obispo y del paborde encargado de su administración. Allí vivió entre los años 1341 y 1342, durante el exilió al que le forzó Pedro el Ceremonioso a causa de la oposición a satisfacer las contribuciones económicas que el monarca exigió a la sede gerundense. La institución del beneficio eclesiástico dedicado a San Carlomagno en una de las capillas de la iglesia de Rupià tuvo un carácter estrictamente familiar, ya que en el momento de su creación Arnau lo confió a su sobrino, el canónigo y futuro obispo Bertran, y en 1347 al hermano de éste, Bernat, antiguo canónigo de la catedral de Mallorca. Una circunstancia que, de nuevo, demuestra hasta que punto la promoción del culto al emperador franco se halla vinculado a la persona del prelado gerundense.

${ }^{41}$ Para ello contó con una autorización del mismo Pedro el Ceremonioso dictada el año 1345. PladeVAll, Arnau i Bertran de Montrodon, p. 406.

«Anuario de Estudios Medievales», 34/1 (2004), pp. 417- 454.- ISSN 0066-5061. 
flanqueado por el obispo Arnau de Montrodon y los miembros del cabildo, presidía ante un buen numero de autoridades y feligreses la ceremonia de consagración del nuevo altar mayor, trasladado in capite novo operis junto inmediate sanctorum diversarum reliquiarum, que in altari antiquo fuerunt reperte, et ad hoc diligencia debita conservate ${ }^{42}$.

De acuerdo con el relato legendario que hemos expuesto uno de los principales objetivos de la campaña de Carlomagno en tierras gerundenses fue la construcción y renovación de diferentes iglesias y cenobios de la diócesis. La culminación de tales empresas y de la propia cruzada tuvo lugar cuando, tras la entrada del emperador en Gerona, se procedió a la fundación de una nueva catedral dedicada a la Virgen en el solar que hasta entonces ocupaba la mezquita musulmana. Está claro que una vez más la figura legendaria de Carlomagno se proyectó bajo el mismo perfil que durante siglos sirvió para consolidar su prestigio como protector de la Iglesia en todo Occidente: el de santo fundador de templos ${ }^{43}$. Huelga decir que la conciencia de la importancia que tuvo este gesto para la historia de la catedral justificaba por si mismo el hecho que fuera recogido en el decreto de institución de la fiesta promulgado por Arnau de Montrodon. Aún más. En el documento episcopal queda claro que la decisión de impulsar del culto al emperador se fundamentaba tanto en la voluntad de reconocer su condición de paladín de la cristiandad, de héroe victorioso frente a los ejércitos musulmanes que ocupaban el territorio gerundense, como al deseo de rendir homenaje a quien desde tiempo atras era considerado patrocinador y primer gran protector de la sede diocesan $a^{44}$.

La voluntad de preservar el recuerdo del emperador por su labor de patronazgo en la catedral gerundense incluso dio lugar a interesantes procesos de mistificación histórica, como se deduce de la lectura de algunas versiones de la leyenda carolina redactadas tan sólo unos años antes de la instauración de la fiesta. Así sucede en un opúsculo, fechado el año 1315, que se encuentra

${ }^{42}$ Liber Notularum, n. 1, fol 50. Transcrito por FITA, Los Reys, p. 106.

${ }^{43}$ Folz, Études sur le culte, p. 11; SHOLOD, Charlemagne, p. 200. Lo mismo sucedió en Cataluña, vid. JASPERT, ¿Dos cultos relacionados? Santiago y Carlomagno, en prensa. El gran prestigio de Carlomagno como fundador de monasterios en el sur de Francia ha sido analizado recientemente por A. REMENSNYDER, Remembering kings past: monastic foundation legends in medieval southern France, Ithaca 1995.

${ }^{44}$ En el texto redactado por el obispo Arnau ambos argumentos son expuestos con meridiana claridad al señalar que la razón fundamental para la invocación a San Carlomagno es que "sostragué per la força de les armes la ciutat de Girona als sarraïns i que fundà i dotà bellament i generosa I'Església gironina, Esposa nostra, i també quasi tots els cenobis de monjos de la nostra Diòcesi". ROURA, L'ofici, p. 42.

«Anuario de Estudios Medievales», 34/1 (2004), pp. 417- 454.- ISSN 0066-5061. 
en un manuscrito procedente del monasterio de Sant Feliu de Guíxols ${ }^{45}$. El texto en cuestión se distingue por la narración de una serie de originales episodios con los que el autor pretende demostrar el especial homenaje y protección que Carlomagno dispensó al cenobio bajoampurdanés. Pero igualmente, y sin que venga a demasiado cuento, nos refiere la curiosa historia de como el emperador conquistó la ciudad de Gerona con la ayuda de varios miembros de la nobleza local, entre ellos el conde Suñer, la condesa Ermessenda y el obispo Pere Roger. Es decir, incorpora una significativa variante a la versión canónica de la leyenda con el inconfesado pero evidente objetivo de establecer un vínculo personal entre Carlomagno y las figuras de otros insignes promotores pretéritos de la sede gerundense que, al menos en el caso de Ermessenda, aún eran recordados y venerados en siglo XIV por su decisiva contribución a la obra del edificio románico ${ }^{46}$. Es muy probable que dicha invención se sustentara en una visión legendaria y al mismo tiempo unitaria de los principales eventos históricos de la catedral gerundense. De ahí, sin ir más lejos, la anacrónica relación entre diversos patrocinadores de la construcción que, en realidad, no sólo nunca se habían conocido entre ellos sino que tampoco habrían podido hacerlo por haber vivido separados por más de dos siglos de distancia! Por último, el hecho que la redacción del opúsculo tuviera lugar en 1315, tan sólo tres años después del inicio de las obras de la cabecera gótica de la sede gerundense, confirma que nos hallamos ante un texto que muy probablemente se gestó en un clima favorable a la cristalización de nuevas leyendas en torno a los inicios de la catedral.

La extraordinaria munificencia de que hizo gala Carlomagno al dotar a la catedral y los cenobios gerundenses con toda clase de bienes y privilegios es otra de las ideas reflejadas con mayor énfasis en el acta de institución de su fiesta ${ }^{47}$. A la vista de ello no debe sorprendernos que la costumbre popular,

${ }^{45} \mathrm{El}$ códice, intitulado Liber porcionus monachorum, fue redactado en la época del abad Tomás Casserra (1290-1328). ACA, Monacals (Benedictins) Reg. 1713, fol. 23; ibid. Reg. 1576, fols. 80-81. Ibid, pp. 41-42.

${ }^{46}$ Sobre la decisiva intervención de la condesa Ermessenda y el obispo Pere Roger durante el siglo XI en la construcción y decoración de la catedral románica, vid. J. MoLINA, Ars Sacra a catedral de Girona. Esplendor i renovació d'una seu entorn a l'any 1000 in Girona a l'Abast, VII-IX, Girona, 2004. A mediados del siglo XIV, se celebraba en la catedral una procesión de carácter funerario que, a su paso por la galilea, lugar donde se encontraba el sepulcro de Ermessenda, recitaba una oración en memoria de la comtessa. Vid. M. SUREDA, Dos itineraris litúrgics per la Girona Medieval i Moderna, "Annals de l'Institut d'Estudis Gironins", XLII (2001), p. 301. Dicha práctica revela bien a las claras hasta que punto el recuerdo de algunos de los principales promotores de la catedral se mantuvo vivo durante siglos.

${ }^{47}$ Vid. supra n. 27.

«Anuario de Estudios Medievales», 34/1 (2004), pp. 417- 454.- ISSN 0066-5061. 
hasta hoy preservada, de relacionar numerosos bienes muebles e inmuebles de la sede episcopal con el patronazgo imperial se remonte precisamente a la primera mitad del siglo XIV ${ }^{48}$. Cabe deducir que un hecho tan trascendental como sería la instauración de un culto sagrado tendría necesariamente importantes efectos en el recuerdo colectivo de la actividad promotora de Carlomagno, legitimando antiguas leyendas y creencias -recordemos que la mayoría de las piezas y obras se remontan a los siglos XI y XII- al tiempo que inspiraba y abría la posibilidad que se gestaran otras de nuevas.

A tenor de estas ideas parece lógico suponer que una de las principales razones que motivaron la decisión de Arnau de Montrodon de implantar el culto a Carlomagno en Gerona en 1345, precisamente en el momento en que se culminaba la primera fase del proyecto arquitectónico de renovación de la sede diocesana, fue la voluntad de homenajear a su mítico fundador, al factotum de la catedral. Tal pretensión no sería extraña ni excepcional. A lo largo de los siglos del medioevo los promotores de importantes reformas de grandes edificios religiosos, en especial catedrales y cenobios vinculados a la monarquía, practicaron la inveterada costumbre de rendir homenaje a los egregios fundadores que les habían precedido en tan emblemática labor. Las fórmulas para concretar dicha tradición fueron muchas. Al respecto conviene recordar aquí que entre las más comunes se cuentan el encargo de esculturas conmemorativas y la dedicación de diversos ceremoniales litúrgicos que, aún sin llegar a promover la instauración de un culto, resultan plenamente indicativos del deseo de otorgar una aureola de prestigio y autoridad a personajes cuasi legendarios ${ }^{49}$.

Llegados a este punto también podemos preguntarnos si el reconocimiento de los méritos de Carlomagno en su doble vertiente de miles christi y fundador de la catedral constituye la clave para desentrañar la curiosa iconografía de la imagen áulica que presidió su altar hasta finales del siglo XIX. Desde tiempo atrás se ha venido señalando que las figuras de los seres híbridos que el emperador holla con sus pies, concebidas de acuerdo con un esquema de signo cristológico y mariano, podrían aludir a su victoria sobre

\footnotetext{
${ }^{48}$ Girbal nos recuerda que ninguna de las fuentes escritas en las que se basa esta tradición atributiva es anterior al siglo XIV. GIRBAL, Carlomagno, p. 227.

${ }^{49}$ Sobre la práctica de instalar imágenes conmemorativas de reyes fundadores y patrocinadores en edificios medievales, vid. E. CARRERO, El confuso recuerdo de la memoria, en I. BANGO, (ed.) Maravillas de la España Medieval. Tesoro Sagrado y Monarquía, s.1. 2001, pp. 90-91.

«Anuario de Estudios Medievales», 34/1 (2004), pp. 417- 454.- ISSN 0066-5061.
} 
la secta musulmana, la herejía, el islamismo; en definitiva, sobre el maP ${ }^{50}$ A pesar de no disponer de apoyos textuales explícitos ni tampoco de paralelos iconográficos, lo cierto es que se trata de una interpretación muy razonable a tenor de los méritos que fundamentaban el prestigio de Carlomagno entre los gerundenses y la frecuente demonización de los enemigos de la fe cristiana $^{51}$. Por la misma razón pienso que igualmente resulta factible pensar que la amputada mano derecha de la imagen pudo sostener un símbolo, como podría ser la maqueta de la catedral, evocador de la decisiva contribución del emperador carolingio a la génesis de la sede gerundense. Dicha hipótesis se sustenta no sólo en la observación de uno de los modelos iconográficos más comunes en la Edad Media a la hora de rememorar la figura de insignes promotores edilicios - desde el abad Desiderio de Montecassino hasta el monarca francés Carlos $\mathrm{V}$, por mentar dos testimonios ejemplares- sino también por su recreación en esculturas e imágenes de Carlomagno realizadas para sedes episcopales del Imperio donde se le veneraba en calidad de fundador $^{52}$ (fig. 6). De acuerdo pues con esta interpretación, la estatua de San Carlomagno ofrecería a los espectadores gerundenses una imagen visual acorde con las creencias y leyendas que fundamentaron su culto a partir de 1345 .

Ahora bien, al margen de la voluntad de evocar el prestigio del emperador carolingio como restaurador de la sede diocesana debemos tener en cuenta otros factores si pretendemos desvelar las auténticas razones que motivaron la institución de la fiesta en su honor. Lejos de constituir un hecho aislado la promoción del culto a Carlomagno en Gerona tuvo lugar en un momento especialmente favorable para la cristalización de devociones religiosas de ámbito local. Los testimonios al respecto son numerosos y, en la mayoría de ocasiones, constituyen un capítulo de la vida litúrgica de la sede diocesana relacionado directa o indirectamente con la acción de Arnau de

${ }^{50}$ Interpretación ya apuntada en E.C. GIRBAL, La estatua de Carlomagno, "Revista de Gerona", XIII (1889), p. 15.

${ }^{51}$ Las formas de representación de las comunidades y grupos -desde judíos y musulmanes hasta paganos, herejes y homosexuales- que vivían excluidos del seno de la Iglesia, confinados en los espacios marginales de la sociedad medieval, es el tema del interesante ensayo de $\mathrm{M}$. CAMILlE, The gothic idol, Cambridge, 1989.

${ }^{52}$ Además de la representación de Frankfurt que aquí ilustramos existe otra en Bremen concebida de acuerdo con el mismo esquema iconográfico. También en Bremen y en Münster se conservan esculturas en las que Carlomagno se representa junto al primer obispo de la sede circunstancia que certifica otra fórmula para señalar la ręlación del emperador con la génesis de la catedral. Para estos y otros testimonios, vid. Folz, Etudes, p. 23 y 52. 
Montrodon. Un buen ejemplo de ello es la instauración en toda la diócesis del culto a los Cuatro Santos Mártires, decretado por este prelado el año 1335, tan sólo unos meses después de acceder a la cátedra episcopa ${ }^{53}$. Además de ocuparse de la redacción de un oficio litúrgico para los santos gerundenses, concebido a partir de la fusión entre materiales comunes y otros de evidente raigambre local, Arnau de Montrodon quiso que la celebración más solemne de la fiesta tuviera lugar en la capilla catedralicia que él mismo había sufragado, un ámbito donde ya con anterioridad había dispuesto que fuese instalada una gran urna-sarcófago que contenía las reliquias de los nuevos $\operatorname{santos}^{54}$ (fig. 7). Unos años más tarde, en 1346, nuestro prelado fue también artífice de una fiesta cuyos fundamentos seguramente están relacionados con la antigua devoción que existía en la sede gerundense hacia las reliquias cristológicas: me refiero a la promulgación del culto a la Corona del Señor en honor a la Santa Espina que desde época románica era venerada en el altar de la Santa $\mathrm{Cruz}^{55}$. Asimismo diversas noticias nos informan que Arnau, durante su etapa como influyente canónigo del Cabildo, ya había dado inequívocas muestras de su afición hacia este tipo de manifestaciones devocionales. De hecho fue precisamente en aquel período, y en concreto durante el obispado de Gastón de Montcada (1328-1334), cuando sabemos que intervino de manera determinante en el promoción de la fiesta de la Concepción de María ${ }^{56}$. Incluso podemos certificar que, una vez elegido obispo, su radio de acción en este terreno sobrepasó con mucho los muros de la catedral, ya que contribuyó decisivamente al proceso de dinamización y popularización del culto a las tumbas de diversos santos venerados en establecimientos monásti-

\footnotetext{
${ }^{53}$ Un año después, en 1336, promovía un beneficio que incluía la obligación de celebrar misas y aniversarios en su honor. Un detallado análisis del culto en G. ROURA, El culte als quatre sants màrtirs de Girona, "Analecta Sacra Tarraconensia", 71 (1998), pp. 711-719.

${ }^{54}$ Para el relato hagiográfico, vid. A.V. DOMENECH, Historia General de los Santos y Varones ilustres en Santidad del Principado de Cataluña, Gerona, 1630, 112-116. Las más recientes aportaciones sobre la cronología, autoría y características de la urna-relicario y de la construcción de la capilla donde fue instalada corresponden a F. ESPAÑOL, L'escultor Joan de Tournai a Catalunya, "Annals de l'Institut d'Estudis Gironins", XXXIII (1994), pp. 398-402; EADEM, Joan Avesta, sculpteur de Carcassone. L'influence de l'atelier de Rieux sur la Catalogne, "Bulletin Monumental", 151-II (1993), pp. 384-386, 401 n. 12.

${ }^{55}$ VILlANUEVA, Viaje literario, XIV, p. 12.

${ }^{56}$ Actes d'Estatuts i de la Canonja. Arxiu Diocesà de Girona, T. 8, núm. 3. Cit. Pladevall, Arnau $i$ Bertran, p. 404.
} 
cos de la ciudad, como parece ser que sucedió en los casos de San Daniel (1343) y del beato Dalmacio Moner (1341) ${ }^{57}$.

Si mesuramos el grado de originalidad y las motivaciones que dieron lugar a todas estas manifestaciones devocionales podemos constatar que nos hallamos ante algo más que frente una particular expresión de la piedad y el gusto por el fasto litúrgico de Arnau de Montrodon. Ante todo cabe reconocer que la política religiosa emprendida por el prelado gerundense presenta numerosos paralelos con las campañas desplegadas por otras autoridades religiosas de su tiempo. Sólo es necesario reunir diversas noticias para comprobar que a lo largo del segundo cuarto del siglo XIV Cataluña fue escenario de un proceso de dinamización e impulso del culto a las reliquias de santos autóctonos. San Narciso en la propia Gerona, Santa Tecla en Tarragona, Santa Eulalia en Barcelona o el beato Mirón en Sant Joan de les Abadesses constituyen algunos de los testimonios más paradigmáticos de un fenómeno que, como no podía ser de otra manera, se materializó mediante la instauración de fiestas cívico-religiosas, la redacción de nuevos oficios litúrgicos y el encargo de monumentales sepulcros-relicarios ${ }^{58}$. En consecuencia bien podemos decir que, al margen de sus inquietudes y sentimientos personales, Arnau de Montrodon se hizo eco - eso sí, de manera ejemplar y casi me atrevería decir exagerada- de una extendida corriente favorable a la promoción de cultos de carácter local. Ello nos ofrece, está claro, un nuevo

\footnotetext{
${ }^{57} \mathrm{La}$ promoción del culto a San Daniel conoció un notable impulso a partir del año 1343 , momento en que tuvo lugar la invención de sus reliquias en el homónimo monasterio femenino fundado más de tres siglos antes por la condesa Ermessenda en las afueras de Gerona. Tan sólo dos años después de este excepcional episodio se encargaba al escultor Aloi de Montbrai la construcción de un notable sepulcro-relicario aún conservado in situ. Aunque no disponemos de ninguna prueba documental directa es muy posible que el obispo Arnau de Montrodon estuviera relacionado directa o indirectamente con todos estos acontecimientos. De hecho sabemos que el prelado gerundense se constituyó en el principal impulsor del culto al mártir, como lo demuestra que ya en el mismo año 1343 dictase una concesión episcopal de indulgencias para todos aquellos que visitaran la tumba y ofrecieran almoinas que ayudaran a financiar la construcción de una nueva capilla funeraria. J.M. MARQUĖs, El sepulcre de Sant Daniel del mestre Aloy, "Revista de Girona", 96 (1981), pp. 196-198. Más hipotética por el momento resulta la relación de Arnau con la figura del beato gerundense Dalmacio Moner, un insigne fraile dominico fallecido el año 1341 en olor a santidad. En cualquier caso es difícil pensar que el obispo se mantuviera al margen de la promoción de un culto que muy pronto obtuvo una notable difusión en Gerona. Y aún más si tenemos en cuenta que los restos del difunto fraile -contenidos en una lauda sepulcral encargada por los marqueses de Santa Pau- fueron venerados en la iglesia del convento de Santo Domingo de Gerona, templo en el que el propio Arnau de Montrodon subvencionó la construcción de una capilla lateral. Agradezco esta última noticia a Mireia Gibert, investigadora que actualmente lleva a cabo un estudio sobre el citado convento dominico.

${ }^{58}$ Los efectos que tuvo la renovación de los cultos hagiográficos en el ámbito artístico han sido recientemente analizados en F. ESPAÑOL, El gòtic català, op. cit., pp. 103-111.
} 
elemento para reconstruir el entorno histórico y religioso en el que se gestó la fiesta en honor a Carlomagno.

Varios son los objetivos que anidan detrás de actuaciones como las que acabamos de describir. Entre aquellos estrictamente religiosos cabría destacar la voluntad de aproximar las figuras de los santos a los fieles, la existencia de un deseo de estimular la veneración a personajes que estaban ligados a la memoria colectiva de los habitantes de un territorio. Ya sea con la divulgación de leyendas hagiográficas autóctonas o con la adopción de medidas encaminadas a potenciar el culto de las reliquias conservadas en una determinada localidad, la idea subyacente era siempre la misma: transformar al santo en un privilegiado protector de la comunidad y, por lo tanto, hacer de su culto un rasgo distintivo de las tradiciones devocionales del lugar. Pero no todas las razones fueron de índole tan desinteresada o, si queremos decirlo de otro modo, espiritual. Durante toda la Edad Media el impulso de muchas devociones, y en especial de aquellas relacionadas con la veneración de cuerpos santos, estuvo fuertemente impregnado de un sentido que hoy calificaríamos de instrumental o propagandístico. Cualquier iglesia o cenobio poseedor de reliquias era consciente de que disponía de un tesoro que no sólo le podía reportar pingues beneficios monetarios a través de las almoinas de los peregrinos sino también, y esto es lo que nos interesa subrayar aquí, de uno de los principales argumentos para consolidar su prestigio y legitimar sus intereses frente a otros centros religiosos. ¿Es factible suponer que tales propósitos inspiraron buena parte de la campaña de promoción de cultos desplegada por Arnau de Montrodon?, ¿Qué la veneración hacia san Carlomagno estuvo animada por el deseo de concretar referentes de prestigio que contribuyeran a la exaltación de la sede gerundense? Y si fue así ¿Qué situación o situaciones vividas en la catedral justificaron o, cuando menos, contribuyeron a que se convirtiera en un activo escenario del impulso a nuevos cultos locales? Para responder a estas preguntas debemos rememorar algunos acontecimientos ocurridos durante la primera mitad del siglo XIV y el papel que en ellos desempeñó Arnau de Montrodon.

En torno al año 1330 la ya antigua reivindicación del condado de Ampurias para que se restableciera su antigua sede episcopal, abolida tras la ocupación musulmana, se convirtió en una grave amenaza para la integridad 
de la diócesis gerundense ${ }^{59}$. El principal valedor del proyecto segregacionista fue el conde Pedro (1325-1341), hijo del rey Jaime II, uno de los más destacados promotores de la iglesia de Santa Maria de Castellón, a la que pretendía convertir en catedral del nuevo episcopado ${ }^{60}$. Gracias a sus numerosos contactos e influencias en la corte aviñonesa el infante logró que el papa Juan XXII se declarara a favor de la creación de una diócesis emporitana, siempre y cuando se obtuviera el respaldo del rey Alfonso III. Ante el cariz que tomaban los acontecimientos, el obispo gerundense Gastón de Montcada decidió enviar en 1332 una delegación a Aviñón encabezada por el canónigo Arnau de Montrodon, quién además de ocupar una privilegiada posición en el cabildo también gozaba de una notable reputación como jurista $^{61}$. En virtud de estas aptitudes poco después se desplazó, ahora en solitario, a la corte del rey Alfonso para exponer los graves prejuicios que la creación del nuevo episcopado ocasionaría a la ciudad de Gerona. Cabe deducir que la habilidad y buenos oficios de nuestro canónigo en ambas sedes surtieron efecto puesto que, al menos de momento, se conjuró el peligro de una escisión de la diócesis gerundense. Sin embargo ello no supuso, ni mucho menos, la resolución de una polémica que, con mayor o menor intensidad, se mantuvo durante buena parte del siglo XIV ${ }^{62}$.

La existencia de un conflicto que, debido a su misma naturaleza, llegó a cuestionar la autoridad del obispo de Gerona puede ayudarnos a comprender el interés que mostró el prelado Arnau de Montrodon hacia la creación de símbolos y manifestaciones del poder episcopal. Pensemos, por ejemplo, en la reutilización de la cátedra románica "de Carlomagno" con motivo de la consagración del año 1347. Conscientes de la enorme potencia visual y

\footnotetext{
${ }^{59}$ Sobre la polémica vid. J. VINCKE, Der Plan eines Bistums Empúries im 14.Jahrhundert en "Homentage a Antoni Rubió i Lluch", II, Barcelona, 1936, pp. 341-358; VILLANUEVA, Viaje literario, XIII, p. 118; J. POU I MARTí, Visionarios, beguinos y fratricelos catalanes, Vic, 1930, pp. 339-340; PladeVAll, Arnau i Bertran, p. 405.

${ }^{60} \mathrm{Las}$ primeras noticias sobre la ambiciosa y retórica construcción se remontan al año 1260 , aunque no fue hasta 1315 cuando sabemos que fue consagrado el altar mayor. Vid. M. PUJOL, El retaule d'alabastre de Santa Maria de Castelló d'Empúries, "Annals de l'Institut d'Estudis Empordanesos" 22 (1989), p. 69; J. MARQUÉS CASANOVAS, La catedral fustrada de Castelló d'Empúries, "Annals de l'Institut d'Estudis Empordanesos", 13 (1978), pp. 93-102. Sobre el infante Pedro, vid. S. SoBreQuÉs, Els barons de Catalunya, 3, Barcelona, 1980, pp. 132-133; D. GENís, Les profecies de l'infant Pere d'Aragó (1305-1381): el comtat d'Empúries en l'inici del joaquinisme a Catalunya, "Annals de l'Institut d'Estudis Empordanesos", 35 (2002), pp. 119140 .

${ }^{61}$ Pladevall, Arnau i Bertran, pp. 405-406.

${ }^{62}$ MARQUÉS, La catedral fustrada, p. 93 documenta en el año 1384 un nuevo y decidido intento de constituir el episcopado emporitano.
}

«Anuario de Estudios Medievales», 34/1 (2004), pp. 417- 454.- ISSN 0066-5061. 
simbólica de este mueble litúrgico realizado en torno al año 1038, los dirigentes de la catedral no sólo se limitaron a reinstalarla en un nuevo escenario templario más espectacular y grandilocuente - una plataforma de más de dos metros de altura levantada detrás nuevo altar mayor gótico- sino que, por encima de cualquier otra idea, buscaron magnificar y proyectar de manera casi teatral todos sus valores tradicionales, consiguiendo de este modo una impresionante proyección escénica de la figura del obispo (fig. 8) ${ }^{63}$. Asimismo, podemos suponer que la intensa campaña de promoción de cultos autóctonos desarrollada por Arnau de Montrodon estuvo animada por el deseo de concretar una especial vinculación personal e institucional con unos personajes sobrenaturales que, al margen de su función devocional, eran susceptibles de ser presentados como auténticos protectores de la autoridad episcopal y la sede diocesana. Dicha circunstancia resulta especialmente evidente al constatar los valores que se desprenden del culto a San Carlomagno, ya que se trataba del fundador de la catedral de Gerona y, en consecuencia, de su diócesis. Con la institución de la fiesta en su honor está claro que se otorgaba una nueva y más poderosa dimensión a un importante símbolo legitimador de la unidad del episcopado gerundense. Una lectura que no podemos despreciar si tenemos en cuenta que su ascenso a los altares se produjo tan sólo unos años después de la grave crisis desatada por las reivindicaciones de los condes de Ampurias, cuando la espada de Damocles encarnada por las demandas de segregación aún planeaba en el ambiente, y que el artífice de la operación fue uno de los personajes más implicados en la polémica.

En otro orden de cosas debemos recordar que el año 1312 señaló el comienzo de un período crucial en la larga historia de la catedral de Gerona. Fue entonces cuando se inició la construcción de la nueva cabecera de estilo gótico coronada por nueve capillas, un ambicioso proyecto con el que se

\footnotetext{
${ }^{63}$ Sobre los particulares valores simbólicos que se desprenden de la cátedra románica y su lectura a partir de unos acontecimientos semejantes a los aquí descritos - en concreto, la institución del obispado de Besalú el año 1017-, vid. Molina, Ars Sacra, op. cit. Dos fueron las intervenciones practicadas en la cátedra en tiempo de Arnau de Montrodon. Por un lado, la retórica y escenográfica colocación del trono sobre la monumental plataforma en la que aún hoy se encuentra. Por el otro la realización en el dorso de un relieve en el que aparecen representados un obispo bendiciente acompañado de cuatro acólitos: dos encargados de sostener sus emblemas y otros dos que desempeñan una función ceroferaria. Sin lugar a dudas el tono mayestático de la imagen y su evidente carácter litúrgico aluden a la función de la cátedra como sede y epicentro de algunas de las ceremonias religiosas presididas por el obispo que sabemos que tuvieron lugar en la catedral gerundense a partir de la época gótica. Vid. M. SUREDA, Dos itineraris litúrgics per la Girona Medieval i Moderna, "Annals de l'Institut d'Estudis Gironins", XLII (2001), pp. 281-303.
}

«Anuario de Estudios Medievales», 34/1 (2004), pp. 417- 454.- ISSN 0066-5061. 
buscaba modernizar y adecuar a las necesidades de la época un templo que por aquel entonces contaba ya con casi tres siglos de existencia ${ }^{64}$. Significativamente ese es también el momento en que el nombre de Arnau de Montrodon empieza a aparecer de manera reiterada en la documentación de la fábrica y la decoración del templo, hasta el punto que su biografía llega a confundirse con la historia del proyecto edilicio. Lo que yo sé es que apenas hubo cosa de importancia en los 38 años de su canonicato en que no haya dado muestras de su actividad, afirmó con acierto el padre Villanueva tras consultar los fondos del archivo capitular ${ }^{65}$. Una primera muestra de ello es la noticia, fechada el mismo año 1312, que nos refiere su designación como miembro de la comisión integrada por tres canónigos encargada de supervisar y financiar las obras ${ }^{66}$. Revestido con el privilegiado status de canónigo obrero, cargo que ocupó durante más de dos décadas, Arnau de Montrodon mantuvo una estrecha relación con los sucesivos arquitectos que dirigieron la fábrica -las informaciones hablan de contactos con Jaume Faveran (1321) y Guillem Cors $(1330)^{67}$ - e incluso con los maestros dedicados a la realización de emblemáticas obras muebles que habían de decorar el nuevo recinto, como es el caso del maestro Bartomeu, autor del retablo de plata del altar mayor $(1325)^{68}$. Su destacada participación en todos estos asuntos ofrece una doble lectura. Ante todo señala que nos hallamos frente a uno de los más decididos inspiradores y promotores del coro gótico, ante una figura clave para comprender la gestación y desarrollo de un monumental proyecto arquitectónico ${ }^{69}$. No en

${ }^{64}$ Un último estudio del edificio de época gótica en P. FreIXAS, La catedral de Girona, en $L$ 'art gòtic a Catalunya. Arquitectura I (Catedrals, monestirs $i$ altres edificis religiosos I), Barcelona, 2002, pp. 302-324.

${ }^{65}$ VILlanUEVA, Viaje literario, XIV, 3.

${ }^{66}$ "Et cura ipsius operis fuit commissa per dictum capitulum venerabilis Raimundo de Vilarico Archidiacono et Arnaldo de Monterotundo canonico et Dalmacio de Podialibus, presbitero de dicto capitulo gerundensi”. Liber Negotiorum Capituli, t. 1, fol. 50. Vid. FITA, Los Reys, p. 102.

${ }^{67}$ Ibid. p. 103 y 105.

${ }^{68}$ Ibid. p. 104.

${ }^{69} \mathrm{Al}$ margen de sus numerosas intervenciones en el recinto templario, en torno del año 1330 también se encargó de llevar a cabo una serie de obras de reforma y mejora en la canónica - "plura et utilia melioramenta fecit in hospicia Canonice, in quo ipse nunc moratur, quod est juxta refectorium ipsiu Ecclesie Gerundensis..."-, por las cuales fue recompensado con la autorización de instítuir un lampadario en la capilla de los Cuatro Santos Mártires (Ibid, p. 105). Asimismo es muy posible que fuera el responsable de la decoración pictórica de la capilla de San Salvador, sita en el Palacio Episcopal. Vid. J. CAlZADA, La Capella de Sant Salvador del Palau Episcopal i les pintures gòtiques suara descobertes, "Revista de Girona", 90 (1980), pp. 25-29.

«Anuario de Estudios Medievales», 34/1 (2004), pp. 417- 454.- ISSN 0066-5061. 
balde el ya citado Villanueva le calificó como el alma de la empresa ${ }^{70}$. Por otro lado, en la medida que con frecuencia actuó en representación del Cabildo gerundense, las intervenciones del canónigo Arnau de Montrodon constituyen una perfecta demostración del importante papel que desempeñó este organismo en todo el proceso de ejecución de la fábrica gótica. De hecho una atenta lectura de la documentación revela que la iniciativa e impulso fundamental de las obras corrió a cargo de los miembros del Cabildo, ya sea a través de acciones a nivel colectivo o a título individual. Una circunstancia, por cierto, bien distinta a la que nos presenta la historiografía tradicional, que aún sigue otorgando un protagonismo desmesurado a los obispos en un empecinado intento de ver en ellos a los principales promotores de la nueva construcción ${ }^{71}$.

\footnotetext{
${ }^{70}$ VILlanueVA, Viaje, XIV, p. 9.

${ }^{71}$ Esta vieja idea es aún formulada por Freixas en su reciente trabajo, en el que leemos que la cabecera gótica fue comenzada "gràcies a l'impuls dels bisbes Bernat de Vilamarí (1292-1312) i Guillem de Vilamarí". FREIXAS, La catedral gótica, p. 305. En realidad los obispos, y en concreto Guillem de Vilamarí, se sumaron a un proyecto iniciado gracias al empeño del Cabildo. De hecho sabemos que la decisión de comenzar las obras se tomó cuando la sede episcopal estaba vacante por la muerte de Bernat de Vilamarí el 30 de enero de 1312, mientras asistía al Concilio de Viena (VILlanUEVA, Viaje, XIII, pp. 196-197). Antes del nombramiento del nuevo prelado el Cabildo decidía, en una solemne reunión celebrada el 29 de abril, promover la construcción de la nueva cabecera. Ese mismo día nombraba la referida comisión de tres miembros encargada de supervisar las obras, para las cuales se destinó una primera partida de 12.000 sueldos procedentes del legado de Guillem Jofre (FITA, Los Reys, p. 102). El nombramiento del nuevo obispo, Guillem de Vilamarí, debió producirse a finales de verano de 1313 , ya que prestó obediencia al arzobispo de Tarragona el VIII idus augusti 1313. En un documento fechado el 23 de septiembre de ese mismo año Guillem reconocía explícitamente la labor promotora del Cabildo al informar que, dada la pequeñez de la catedral de Santa María y las incomodidades que ello comportaba para celebrar los oficios, "els prelats, canonges, preveres i els clergues del capítol de l'església de Girona, unànimement, trobant-se aquesta seu vacant, van establir i ordenar que s'engrandís i ampliés el prebiteri de l'església" (FREIXAS, La catedral gòtica ..., p. 304). A inicios del siglo XIX, y tras un detallado estudio de la documentación, Villanueva reconocía explícitamente que Guillem de Vilamarí "halló resuelta la construcción de la nueva iglesia catedral" (VILlaNUEVA, Viaje, XIII, p. 200). En una constitución dictada el 1 de mayo de 1313, el prelado establecía conjuntamente con el cabildo que "todas las capellanías que excediesen el valor de 150 sueldos barceloneses de terno, solo pudiesen conferirse en adelante a los prelados, canónigos, presbíteros y clérigos de esta iglesia" (Ibid.). La adopción de esta medida reforzó aún más el papel dominante y dominador de los miembros del Cabildo Mayor, que así pasaban a controlar la construcción y gestión de las nuevas capillas levantadas en el deambulatorio. Llegados a este punto, cabe recordar que el Cabildo Mayor estaba integrado por representantes de importantes familias de la pequeña y mediana nobleza (los Vilamarí, los Montrodon, los Cruïlles...) que, haciendo gala de una interesada munificencia, acabaron por constituirse en los principales promotores de los ámbitos secundarios de la cabecera gótica. Su protagonismo a nivel individual y colectivo en todo el proceso constructivo se ajusta perfectamente a la situación descrita por Freigang en las catedrales del Sur de Francia. Según este historiador alemán, los casos de Narbona, Rodez y Toulouse demuestran que los cabildos fueron los auténticos patrocinadores de sus respectivos templos y que la intervención de los prelados, aún siendo importante, fue siempre puntual y no afectó al conjunto del proyecto. C. FREIGANG, Imitare ecclesias nobiles. Die Kathedralen von Narbonne, Toulouse und Rodez und die franzosische Rayonantgotik im Languedoc, Worms, 1992; ID., Les rois, les éveques et les cathedrales de Narbonne, de Toulouse
} 
Otro importante aspecto a considerar se desprende de la propia naturaleza de la empresa arquitectónica desarrollada en Gerona. Hasta hoy se ha supuesto que el objetivo de los promotores de la reforma de la catedral era única y exclusivamente la construcción de un testero de estilo gótico levantado conforme a los modelos practicados en Narbona y Barcelona. Hoy, sin embargo, disponemos de suficientes indicios para pensar que fue precisamente durante el período de ejecución de esta cabecera, entre los años 1312 y 1347 , cuando tomó cuerpo la idea de proseguir las obras de acuerdo con un arriesgado proyecto de nave única sin paralelos conocidos hasta entonces (fig. 9). Además de las hipótesis de Freigang, quién recientemente se ha declarado a favor de esta posibilidad a partir de una serie de consideraciones de carácter técnico y constructivo ${ }^{72}$, una detenida lectura de las declaraciones de los maestros de obras convocados en las reuniones de los años 1386 y 1415-16 permite comprobar que el plan de nave única ya se habría perfilado en tiempos del arquitecto Jaume Faveran (1321-1330) o, al máximo, antes de la consagración de la cabecera el año $1347^{73}$. Es decir, que la aspiración de erigir un espectacular e innovador edificio, un unicum arquitectónico concebido a partir de los parámetros del gótico meridional, quedó claramente definida durante el período en que Arnau de Montrodon ejercía amplias

et de Rodez, "Cahiers de Fanjeaux, 30 (La Cáthedrale, XII-XV siècles), Toulouse, 1995, pp. 145183.

${ }^{72}$ ID., "Els arcs de mig punt $\mathrm{i}$ els pilars dels revoltons rectes, així com les voltes del deambulatori i la unió entre la nau i el cor (...) són resultat del canvi d'actitud, a causa de la intervenció de Jaume de Faveran (...). Va ser, doncs, Jaume de Faveran qui va concebre la gran nau única...". ID., L'Europa de les catedrals. Gènesi $i$ transformació d'un llenguatge arquitectònic universal, en La catedral de Girona. L'obra de la Seu, Girona, 2003, p. 37.

${ }^{73}$ Durante la consulta celebrada los años 1416-17 Guillem Sagrera indicó "ésser veritat que lo dit cap fou fet e acabat ab intenció que la altra obra, si fahés es seguís a una nau". VILLANUEVA, Viaje, p. 334. La contundente afirmación despeja cualquier duda posible sobre el hecho que el proyecto de nave única es anterior a la finalización de la nueva cabecera gótica. Ya con motivo de la reunión de maestros de obras del año 1386 un grupo de canónigos favorables al proyecto de nave única impulsó la redacción de un alegato en el que se exponía que "des que s'havien iniciat les obres havien passat uns quaranta anys sense que la traça hagués estat objecte de discussió ni de rebuig i que qualsevol canvi en aquells moments seria molt perniciós i detestable" (SERRA RÀFOLS, La nau de la Seu de Girona, en "Miscel-lània Puig i Cadafalch", vol. I, Barcelona, 1947-1951, p. 204), de lo que se deduce que la idea de levantar un edificio de nave única se remontaba a los años 40 . De tales planteamientos también se desprende otra conclusión: que la fábrica gótica abierta en 1312 no sólo tenía como objetivo construir un nuevo testero, como se ha ido repitiendo desde hace décadas (vid. FREIXAS, La catedral, pp. 303-305), sino una nueva catedral que substituyera la antigua sede románica por completo. Que los avatares de la historia obligaran a dilatar el inicio de las obras de la nave durante casi un siglo es una cuestión que no debe hacernos perder de vista lo que aquí nos interesa subrayar: que durante la primera mitad del siglo XIV se concretó un grandilocuente proyecto arquitectónico para la catedral gerundense.

«Anuario de Estudios Medievales», 34/1 (2004), pp. 417- 454.- ISSN 0066-5061. 
competencias sobre el proyecto constructivo, primero desde su puesto de canónigo obrero y, a partir de 1336, como obispo.

Aún suponiendo que nuestro personaje tuviera una inclinación natural hacia la figura de Carlomagno - ya sea por su afición a la historia o por razones de carácter devocional- es muy posible que este sentimiento cobrara un mayor vigor y hallase los auténticos motivos para su expresión ritualizada durante el proceso de gestación de la ambiciosa propuesta arquitectónica que acabamos de describir. Cabe tener en cuenta que, en muchas ocasiones, la promoción de emblemáticos edificios religiosos medievales corrió paralela a la búsqueda de argumentos históricos y sagrados, a la definición de una especie de pasado mítico que sirviera para otorgar una aureola de prestigio y autoridad a la nueva construcción. A partir de esta óptica resulta lógico suponer que uno de los principales objetivos de la institución del culto a Carlomagno debió ser precisamente el. deseo de potenciar los perfiles más maravillosos del imaginario que rodeaba la sede gerundense. La misma excepcionalidad de la acción junto con sus implicaciones simbólicas revelan que Arnau de Montrodon fue muy consciente de la necesidad de nutrir, con materiales histórico-legendarios, una ideología que permitiera sustentar programáticamente la construcción del que estaba llamado a ser uno de los edificios más impresionantes del gótico catalán. Todo ello señala igualmente que nos hallamos ante un feliz encuentro: el de un personaje y una monumental empresa arquitectónica; el de una inquieta y acusada personalidad que supo entrever cuales eran los recursos más adecuados para proyectar una imagen grandilocuente y retórica de la catedral donde residió durante más de medio siglo.

Ciertamente parece difícil pensar que una actuación de esta naturaleza fuera concebida únicamente ad maiorem gloriam de la sede gerundense. Entre muchas otras cosas, Arnau de Montrodon fue un hombre que siempre se distinguió por su inclinación a la búsqueda del prestigio personal y familiar. De ahí que durante su episcopado no dudara en hacer uso en beneficio propio de los recursos que le confería su privilegiada posición. Dan fe de ello la decidida promoción de algunos de sus familiares, en concreto sus sobrinos Bertran y Bernat, a importantes dignidades eclesiásticas de la diócesis mediante actuaciones que incluso dieron lugar a una serie de denuncias por nepotismo que llegarían a ser investigadas en la Curia papal de Aviñón ${ }^{74}$.

\footnotetext{
${ }^{74}$ Español, Joan Avesta, sculpteur de Carcassone, p. 400, nota 8; PladeVAll, Montrodon, p. 119.

«Anuario de Estudios Medievales», 34/1 (2004), pp. 417- 454.- ISSN 0066-5061.
} 
Igualmente significativo puede resultar su interés por la cristalización de importantes símbolos de poder, como las ya mentadas cátedras episcopales, o por la "apropiación" de los nuevos cultos a los Cuatro Santos Mártires y a San Carlomagno, confinados a la capilla que él mismo había costeado. En resumen, actuaciones que revelan su capacidad para otorgar una fuerte dimensión personal a algunas de las intervenciones más destacadas de su periodo de gobierno de la diócesis. Conscientes como somos ahora del crucial papel que Arnau de Montrodon desempeñó en la campaña de renovación arquitectónica de la catedral parece lícito plantearnos sí en su atracción hacia la figura de Carlomagno también influyó el deseo de reivindicar la figura de quién, desde su óptica de obispo constructor, podría ser visto como su ilustre predecesor. En definitiva, de considerar la promoción del culto al emperador carolingio, al legendario fundador y constructor de la primera catedral, como una manifestación más del deseo de Arnau de Montrodon de orquestar los medios necesarios para proyectar una grandilocuente imagen de sí mismo. 


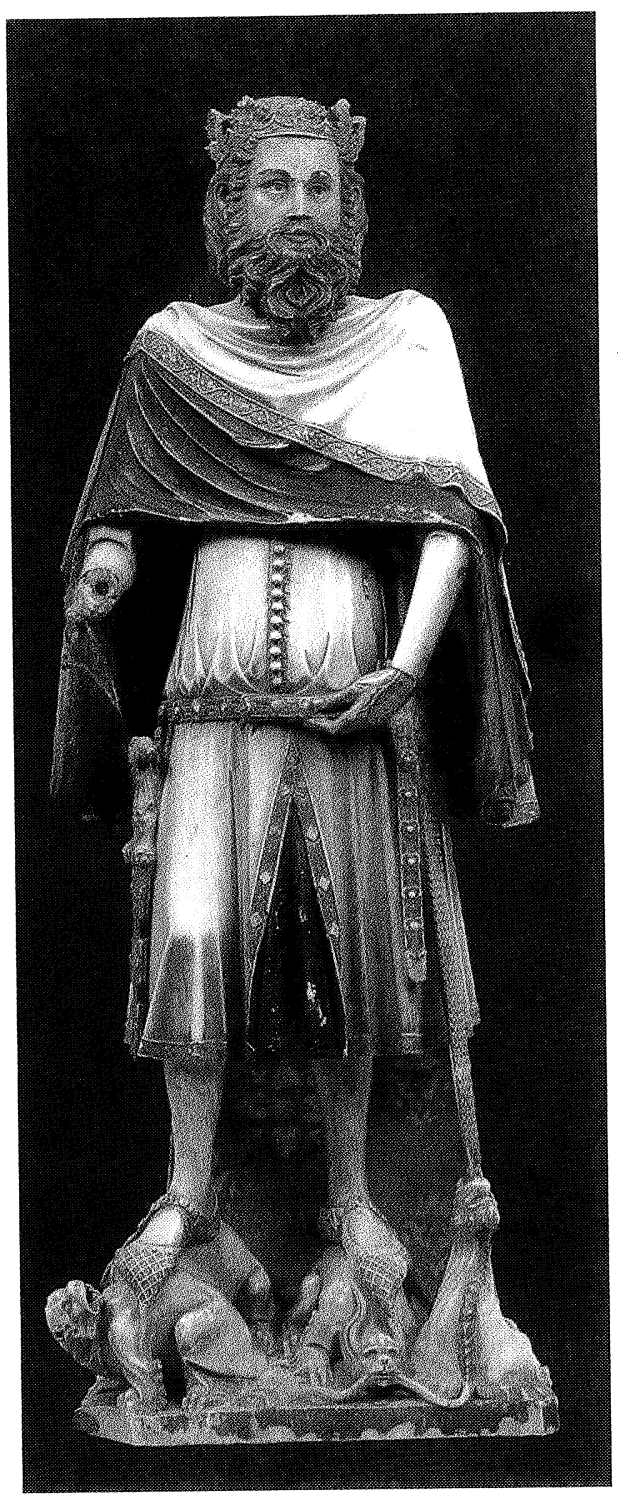

Fig. 1. San Carlomagno. Atribuido a Jaume Cascalls. (Museo de la Catedral de Gerona). 


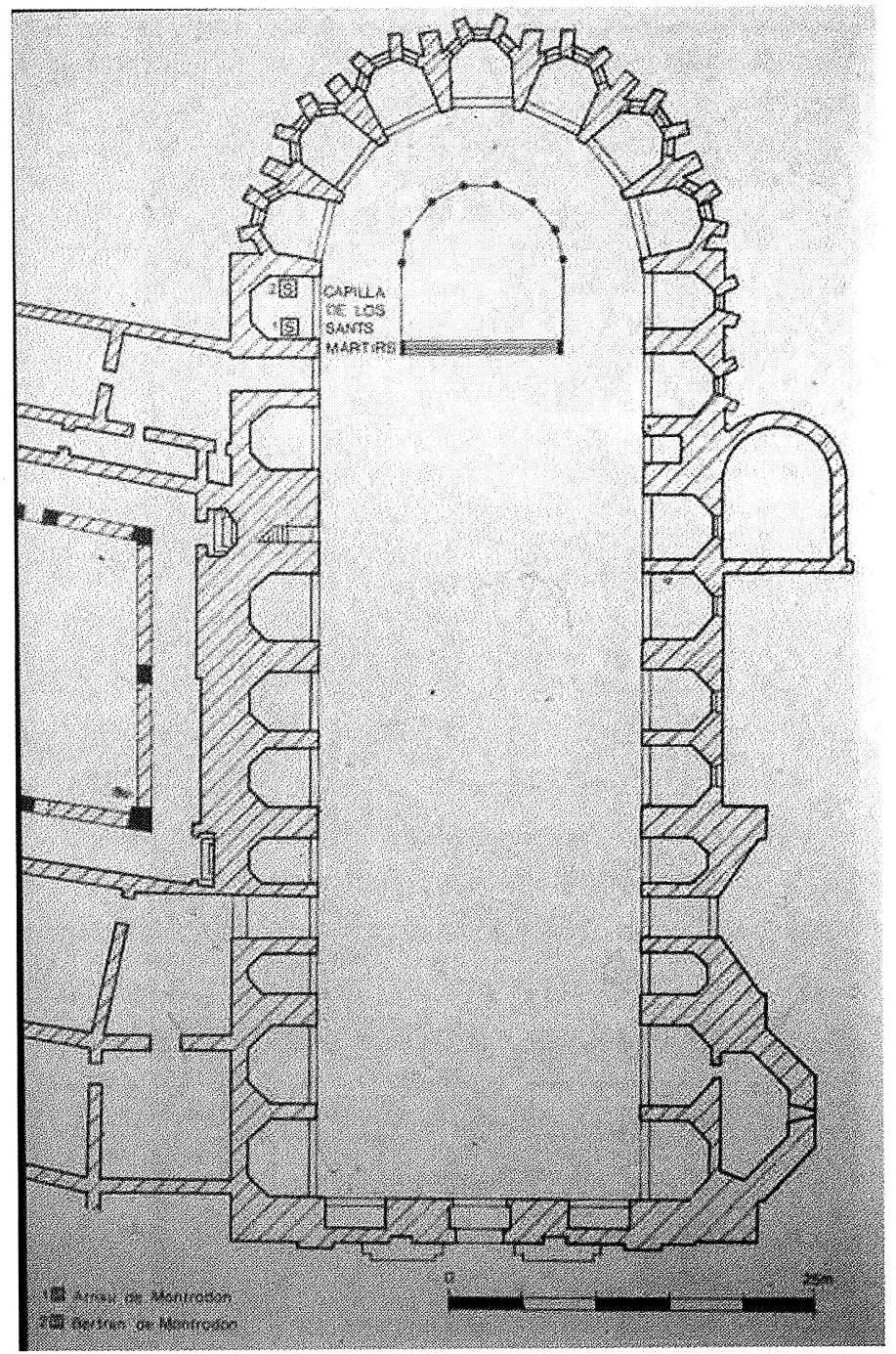

Fig. 2. Capilla de los Cuatro Santos Mártires. (Catedral de Gerona). 


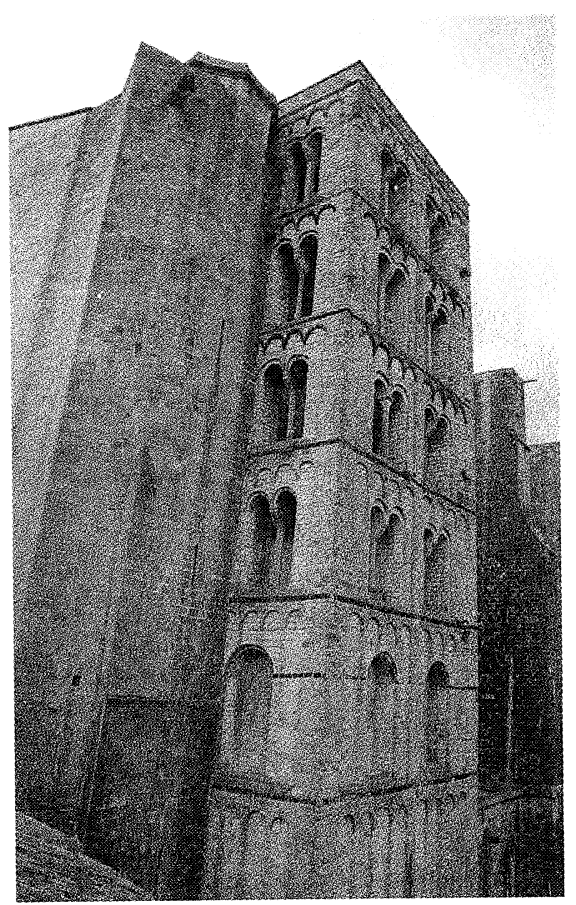

Fig. 3. Torre de Carlomagno.

(Catedral de Gerona).

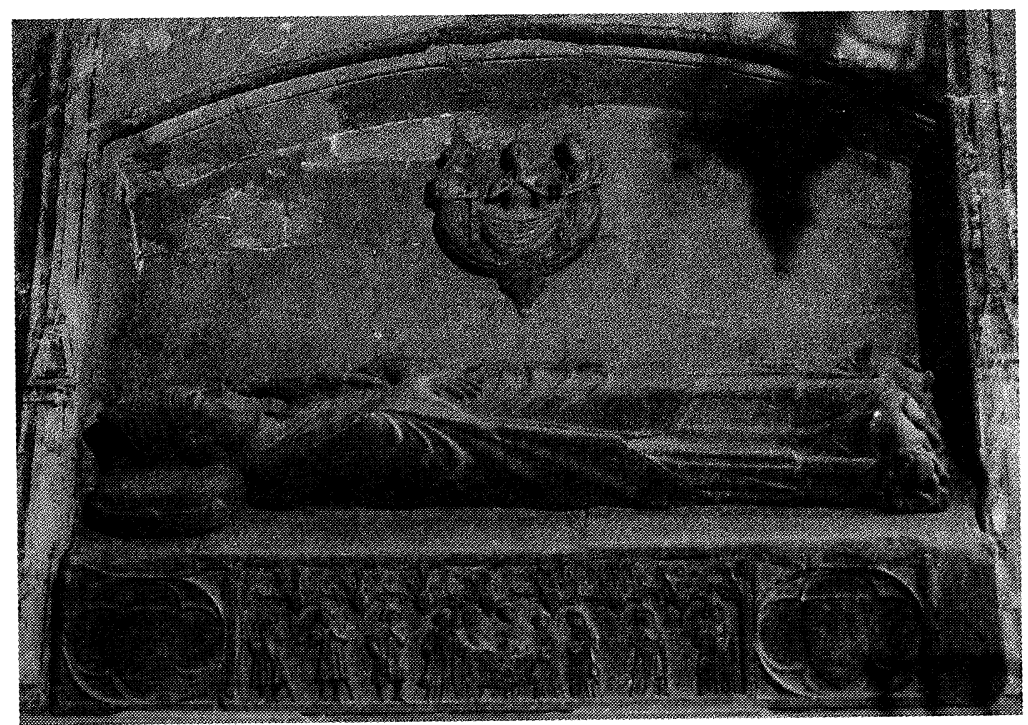

Fig. 4. Sepulcro de Arnau de Montrodon. 


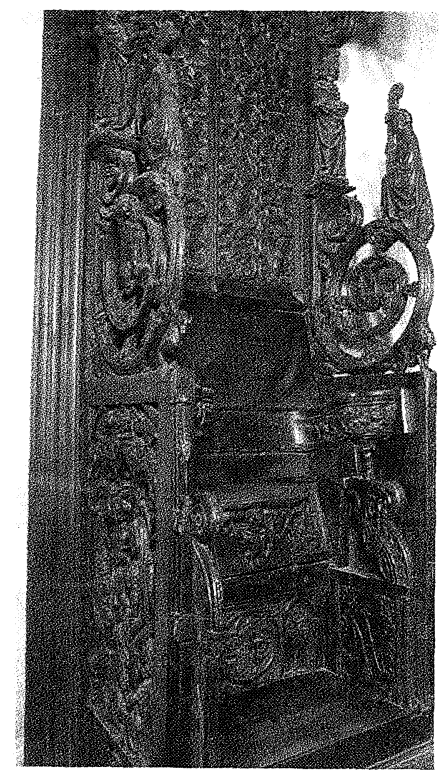

Fig. 5. Cátedra episcopal. Capilla del Santísimo Sacramento. (Catedral de Gerona).

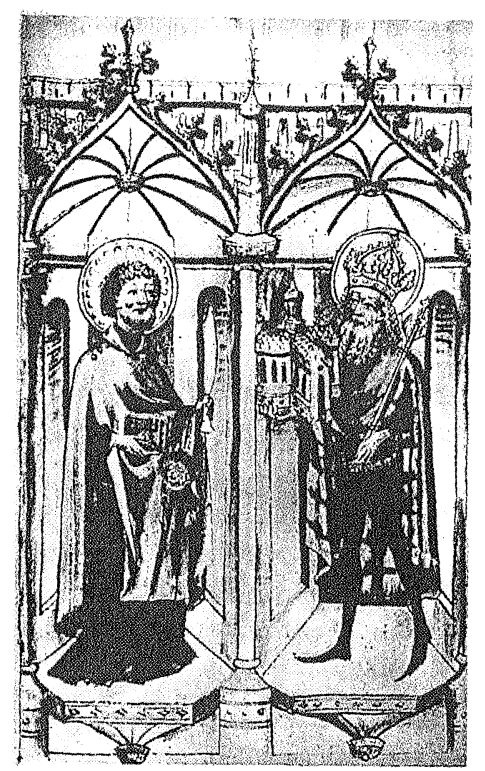

Fig. 6. Carlomagno presenta a san Bartolomé el modelo de la iglesia de Frankfurt. (Ms Barth III, ms. 14. Archivo Municipal de Frankfurt). 


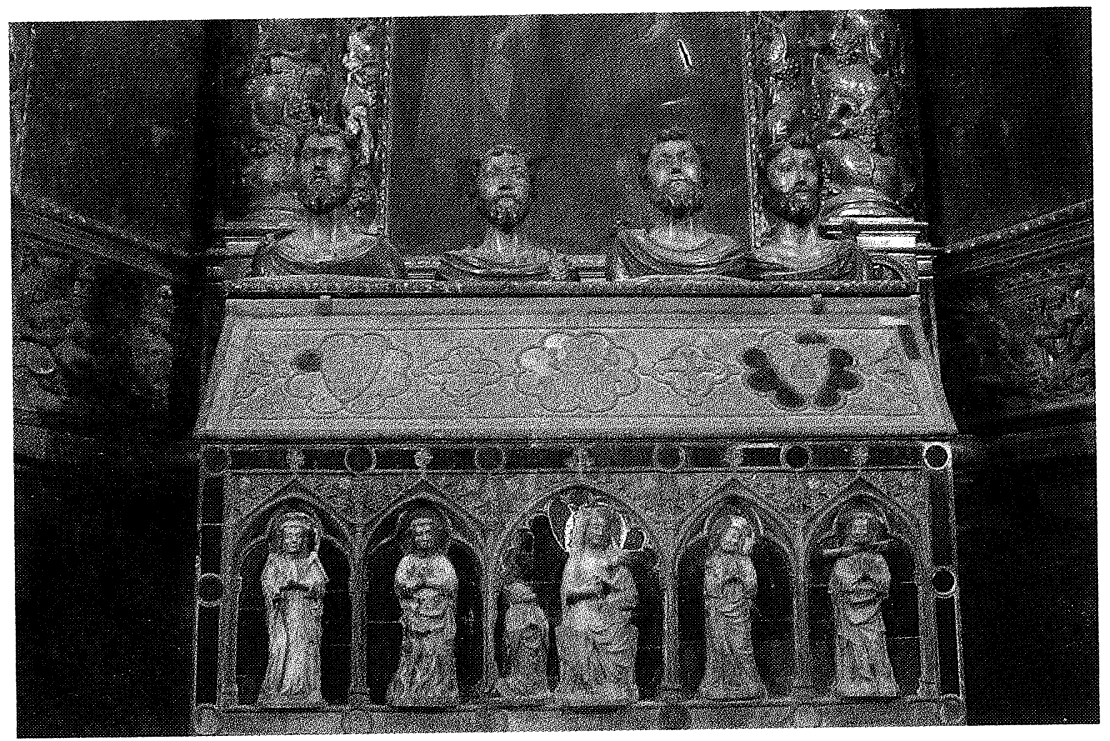

Fig. 7. Urna-relicario de los Cuatro Santos Mártires.

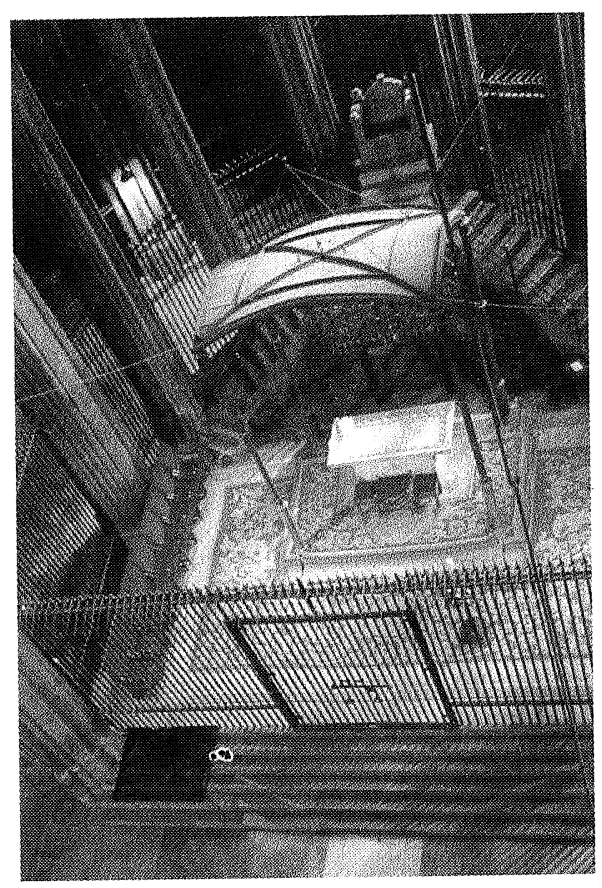

Fig. 8. Altar Mayor de la catedral de Gerona. 


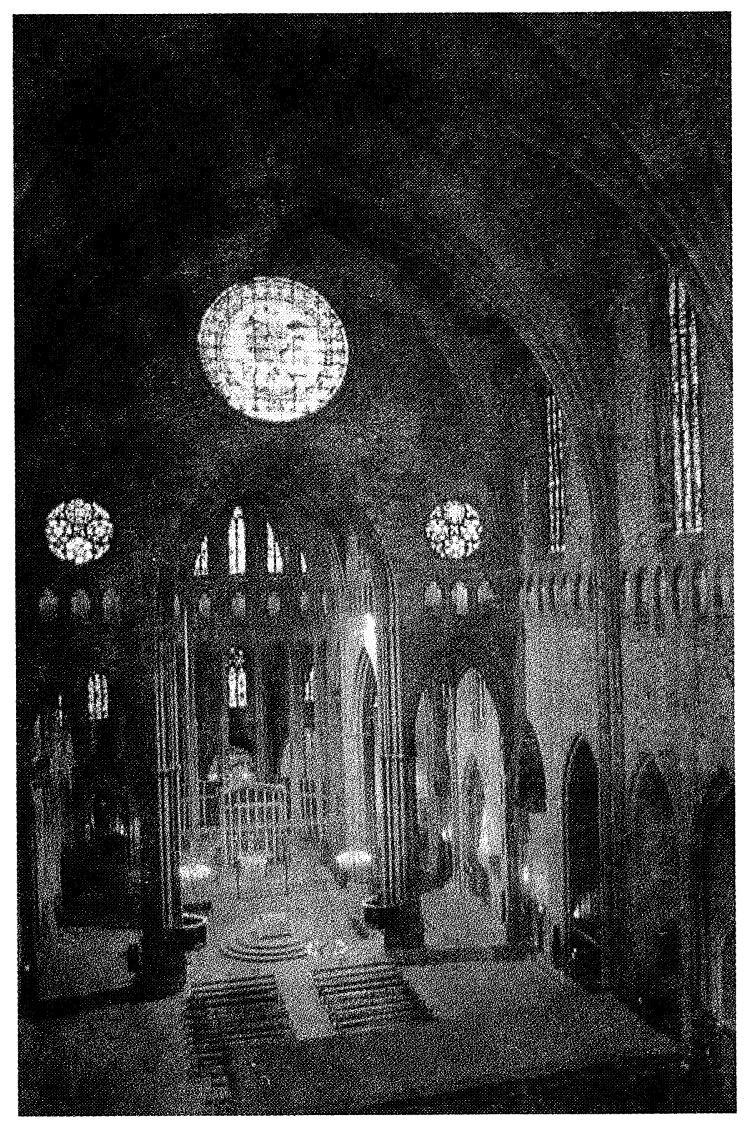

Fig. 9. Vista de la nave única de la catedral de Gerona. 